This document is the unedited Author's version of a Submitted Work that was subsequently accepted for publication in Journal of Natural Products, copyright (C) American Chemical Society after peer review.

To access the final edited and published work see

http://dx.doi.org/10.1021/acs.jnatprod.6b00240 


\section{Phytochemical Investigations of Three Rhodocodon (Hyacinthaceae Sensu APG II) Species}

Sianne Schwikkard, ${ }^{*}+\neq$ Alaa Alqahtani, ${ }^{\dagger}$ Walter Knirsch, ${ }^{\S}$ Wolfgang Wetschnig, ${ }^{\S}$ Andrius Jaksevicius, ${ }^{\ddagger}$ Elizabeth I. Opara, ${ }^{\ddagger}$ Moses K. Langat, ${ }^{\dagger}{ }_{\perp}$ Jackie L. Andriantiana, $\|$ and Dulcie A. Mulholland ${ }^{\dagger, \perp}$

${ }^{\dagger}$ Natural Products Research Group, Department of Chemistry, Faculty of Engineering and Physical Sciences, University of Surrey, Guildford, GU2 7XH, United Kingdom

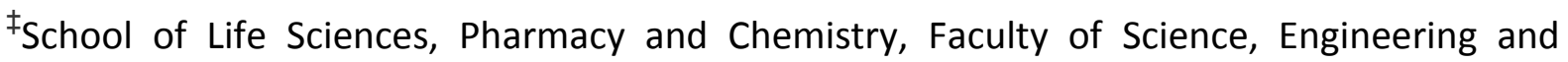
Computing, Kingston University, Penrhyn Road, Kingston Upon Thames, KT1 2EE, United Kingdom

§Institute of Plant Sciences, NAWI Graz, Karl-Franzens-University Graz, Holteigasse 6, A8010, Graz, Austria

${ }^{\perp}$ School of Chemistry and Physics, University of KwaZulu-Natal, Durban, 4041, South Africa "Parc Botanique et Zoologique de Tsimbazaza, Rue Kasanga Fernand, Antananarivo 101, Madagascar 


\section{ABSTRACT}

The genus Rhodocodon (Hyacinthaceae sensu APG II) is endemic to Madagascar and its phytochemistry has not been described previously. The phytochemistry of three species in this genus has been investigated and eight compounds, including three bufadienolides (compounds 1, 4, and 5), a norlignan (2), and four homoisoflavonoids (compounds $\mathbf{3}$ and $\mathbf{6}$ 8) have been isolated and identified. Compounds 1-3 and 6-8 have not been described previously. The COX-2 inhibitory activity of compound 6 and compound 7 acetate (compound 7A) were investigated on isolated colorectal cancer cells. Compounds 6 and 7A inhibited COX-2 by $10 \%$ and $8 \%$, respectively, at a concentration of $12.5 \mu \mathrm{M}$ compared to $12 \%$ for $1 \mathrm{mM}$ aspirin (the positive control). 
Rhodocodon Baker has recently been reinstated as a genus ${ }^{1}$ within the Urgineoideae subfamily of the Hyacinthaceae (sensu APG II). Taxonomic and phylogenetic work $^{1-3}$ has shown that all species of Rhodocodon, a genus endemic to Madagascar, form a well supported monophyletic clade.

Homoisoflavonoids isolated from the Hyacinthaceae family (sensu APG II) have been shown to have anti-inflammatory effects using a mouse edema test. ${ }^{4}$ In addition, homoisoflavonoids with a benzylidene group at C-3 together with a 3',4'-disubstituted Bring and a 5,7-disubstituted A-ring have been shown to exhibit inhibitory activity against cyclooxygenase 2 (COX-2), which is a key mediator of the inflammatory response. ${ }^{5}$ COX-2 is induced in the early stages of a number of cancers and is known to be over-expressed in patients with one of the most common cancers in high-income countries, colorectal cancer (CRC) ${ }^{6-13}$ Furthermore, this over-expression is linked to poor prognosis in those with CRC. $^{14,15}$ Thus, targeting this enzyme is considered to be of importance in the prevention and treatment of CRC. ${ }^{16}$

The phytochemistry of members of this genus has not been reported previously and the phytochemical investigations of three Rhodocodon species are reported herein: Rhodocodon calcicola Knirsch, Mart.-Azorín \& Wetschnig, Rhodocodon campanulatus Knirsch, MartAzorín \& Wetschnig, and Rhodocodon aff. intermedius Knirsch, Mart.-Azorín \& Wetschnig. Investigations into the COX-2 inhibitory activity of the compounds isolated were conducted on colorectal cancer cells in vitro. These species grow in deciduous, seasonally dry western forest at low elevation.

\section{RESULTS AND DISCUSSION}

An ethanol extract of the bulbs of $R$. campanulatus yielded three previously unreported compounds: a bufadienolide glycoside (1), a norlignan (2), a class of compounds rarely reported from the Hyacinthaceae, ${ }^{17}$ and a homoisoflavonoid (3). While bufadienolides are the expected constituents of a member of the Urgineoideae, homoisoflavonoids are rarely found in this subfamily. ${ }^{18}$ The homoisoflavonoid was found to have the rare (3S) configuration.

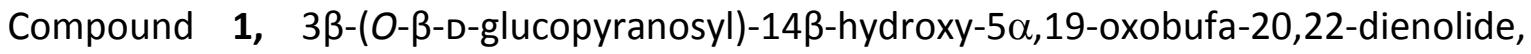
was found to be the $3 \beta-O$-D-glucoside derivative of 19 -oxo-bufalin, which was isolated previously from the Chinese traditional medicine "Ch'an Su", produced from the skin secretions of the toads Bufo gargarizans Cantor or Bufo melanostrictus Schneider. ${ }^{19}$ 
HRESIMS indicated a molecular formula of $\mathrm{C}_{30} \mathrm{H}_{42} \mathrm{O}_{10}$. The FTIR spectrum showed bands at $3419\left(\mathrm{OH}\right.$-stretch), 1732, and $1715 \mathrm{~cm}^{-1}$ (aldehyde and $\alpha, \beta$-unsaturated carbonyl stretches, respectively). The characteristic ${ }^{1} H$ NMR resonances for $\alpha$-pyrone ring protons of a bufadienolide occurred at $\delta_{\mathrm{H}} 7.47(\mathrm{H}-21, \mathrm{dd}, J=0.9 \mathrm{~Hz}, 2.5 \mathrm{~Hz}), 8.01(\mathrm{H}-22, \mathrm{dd}, J=2.5 \mathrm{~Hz}, 9.7$ $\mathrm{Hz}$ ) and $6.29(\mathrm{H}-23, \mathrm{dd}, J=9.7 \mathrm{~Hz}, 0.9 \mathrm{~Hz})$. The $\mathrm{H}-21$ and $\mathrm{H}-22$ resonances showed correlations in the $\mathrm{HMBC}$ spectrum with a methine carbon resonance $\left(\delta_{C} 52.2\right)$ that could be assigned to $\mathrm{C}-17$. The $\mathrm{HMBC}$ spectrum showed correlations between the $\mathrm{C}-17$ resonance and the only methyl group proton resonance, which was assigned as $\mathrm{CH}_{3}-18\left(\delta_{H} 0.68, s\right)$ and between the corresponding $\mathrm{H}-17$ resonance $\left(\delta_{\mathrm{H}} 2.56\right.$, dd, $\left.J=6.4 \mathrm{~Hz}, 9.5 \mathrm{~Hz}\right)$ and an oxygenated carbon resonance $\left(\delta_{c} 85.6\right)$, which was assigned as $C-14$, and hence a hydroxy group was placed at this position. Thus, the usual $\mathrm{CH}_{3}-19$ methyl group was oxidized to an aldehyde. The $\mathrm{H}-19$ resonance $\left(\delta_{H} 10.02, s\right)$ showed correlations with the $\mathrm{C}-1\left(\delta_{C} 32.3\right), \mathrm{C}-5$ $\left(\delta_{C} 44.2\right)$, and $C-10\left(\delta_{C} 53.0\right)$ resonances. The $C-5$ resonance showed a correlation with the $\mathrm{H}-3$ resonance $\left(\delta_{\mathrm{H}} 3.79, \mathrm{~m}\right)$. A NOESY experiment showed correlations between the aldehyde proton resonance and the $\mathrm{H}-1 \beta\left(\delta_{\mathrm{H}} 2.45\right), \mathrm{H}-2 \beta\left(\delta_{\mathrm{H}} 2.02\right), \mathrm{H}-4 \beta\left(\delta_{\mathrm{H}} 1.32\right)$, and $\mathrm{H}-8$ $\left(\delta_{\mathrm{H}}\right.$ 1.64) resonances. No correlation was seen between the $\mathrm{H}-5$ and $\mathrm{H}-19$ resonances. Correlations were observed between the $\mathrm{H}-3 / \mathrm{H}-5, \mathrm{H}-3 / \mathrm{H}-4 \alpha\left(\delta_{\mathrm{H}} 1.96\right), \mathrm{H}-3 / \mathrm{H}-2 \alpha\left(\delta_{\mathrm{H}} 2.02\right)$, and $\mathrm{H}-3 / \mathrm{H}-1 \alpha\left(\delta_{\mathrm{H}}\right.$ 1.06) resonances, confirming both $\mathrm{H}-3$ and $\mathrm{H}-5$ to be in the $\alpha$-configuration and the sugar residue to be located at the $3 \beta$-position (Figure 2 ).

The sugar was identified as $\beta$-D-glucose due to the chemical shifts of the sugar proton resonances and $J_{1^{\prime}, 2^{\prime}}$ and $J_{3^{\prime}, 4^{\prime}}$ coupling constants $(9.0 \mathrm{~Hz}$ and $9.5 \mathrm{~Hz}$ respectively), indicating a trans-diaxial relationship in each case. This was supported by correlations seen in the NOESY spectrum between the $\mathrm{H}-\mathrm{1}^{\prime} / \mathrm{H}-3^{\prime}$ and $\mathrm{H}-\mathrm{2}^{\prime} / \mathrm{H}-4^{\prime} / 2 \mathrm{H}-6^{\prime}$ resonances. ${ }^{20}$ The glycoside derivative of 19-oxobufalin has not been reported previously.

Compound $\mathbf{2}$ is a new norlignan, with a previously unreported skeleton, isolated as its diacetyl derivative, compound $\mathbf{2 A}$, after acetylation of a complex mixture to aid separation. The HRESIMS gave a $[\mathrm{M}+\mathrm{Na}]^{+}$ion at $\mathrm{m} / \mathrm{z} 479.1253$, indicating a molecular formula of $\mathrm{C}_{24} \mathrm{H}_{24} \mathrm{O}_{9}$ for $2 \mathrm{~A}$. The FTIR spectrum exhibited a broad $\mathrm{C}=\mathrm{O}$ absorption band at $1769 \mathrm{~cm}^{-1}{ }^{21}$ The ${ }^{1} \mathrm{H}$ NMR spectrum showed the presence of six aromatic proton resonances due to two 1,3,4-trisubstituted aromatic rings. Resonances could be assigned to the $\mathrm{H}-2\left(\delta_{H} 6.71, \mathrm{~d}, \mathrm{~J}=\right.$ $1.9 \mathrm{~Hz}), \mathrm{H}-5\left(\delta_{\mathrm{H}} 6.87, \mathrm{~d}, J=8.1 \mathrm{~Hz}\right), \mathrm{H}-6\left(\delta_{\mathrm{H}} 6.64, \mathrm{dd}, J=1.9 \mathrm{~Hz}, 8.1 \mathrm{~Hz}\right), \mathrm{H}-2^{\prime}\left(\delta_{\mathrm{H}} 7.43, \mathrm{~d}, J=\right.$ 
$1.9 \mathrm{~Hz}), \mathrm{H}-5^{\prime}\left(\delta_{\mathrm{H}} 7.10, \mathrm{~d}, J=8.1 \mathrm{~Hz}\right)$, and $\mathrm{H}-6^{\prime}\left(\delta_{\mathrm{H}} 7.20, \mathrm{dd}, J=1.9 \mathrm{~Hz}, 8.1 \mathrm{~Hz}\right)$ protons and carbon resonances for the two rings using the HSQC and HMBC spectra. Two methoxy groups $\left(\delta_{H} 3.66\right.$ and $\left.\delta_{H} 3.87\right)$ were placed at $C-3$ and $C-3^{\prime}$ due to correlations seen in the NOESY spectrum with $\mathrm{H}-2$ and $\mathrm{H}-2$ ' resonances, respectively, and the two acetate groups $\left(\delta_{\mathrm{H}}\right.$ 2.29 and $\delta_{H}$ 2.33) were placed at the remaining C-4 and C-4' positions on the aromatic rings based on correlations seen in the HMBC spectrum. The HMBC spectrum showed correlations between a keto group carbon resonance $\left(\delta_{C} 195.3, C-7^{\prime}\right)$ and the $H-2^{\prime}, H-6^{\prime}$ and $2 \mathrm{H}-9^{\prime}$ proton resonances $\left(\delta_{\mathrm{H}} 4.44, \mathrm{t}, J=8.1 \mathrm{~Hz}, 4.11, \mathrm{t}, J=8.1 \mathrm{~Hz}\right)$. The COSY spectrum showed a coupled system incorporating the two $\mathrm{H}^{-9} 9^{\prime}$ protons, $\mathrm{H}-8^{\prime}(\delta 3.07, \mathrm{dd}, J=9.1 \mathrm{~Hz}$, 16.7 Hz), H-7 $(\delta 3.56, d t, J-=6.1 \mathrm{~Hz}, 9.1 \mathrm{~Hz})$ and two $\mathrm{H}-8\left(\delta_{\mathrm{H}} 3.07, \mathrm{~d}, J=6.2 \mathrm{~Hz}\right)$ resonances. The two $\mathrm{H}-9^{\prime}, \mathrm{H}-7$ and two $\mathrm{H}-8$ resonances showed a correlation in the $\mathrm{HMBC}$ spectrum with a lactone carbonyl resonance at $\delta_{C} 176.9$, which was assigned as C-9.

The NOESY spectrum was used to assign the relative configuration of compound $\mathbf{2 A}$. Correlations were seen between the $\mathrm{H}-7$ signal and one of the $\mathrm{H}-9^{\prime}$ proton resonances $\left(\delta_{H}\right.$ 4.11), and between the second $\mathrm{H}-9^{\prime}\left(\delta_{\mathrm{H}} 4.44\right)$ resonance and the $\mathrm{H}-8^{\prime}$ resonance. The large $J_{7,8^{\prime}}$ coupling constant $(9.1 \mathrm{~Hz})$ confirmed a trans relationship between $\mathrm{H}-7$ and $\mathrm{H}-8^{\prime}$. Two structures, $\left(\mathbf{X}: 7 R, 8^{\prime} S\right)$ or $\left(\mathbf{Y}: 7 S, 8^{\prime} R\right)$, were now possible.

ECD studies were used to determine the absolute stereostructure of compound 2A. A conformational analysis using molecular mechanics force fields (MMFF) on SPARTAN08 software was undertaken for $\mathbf{X}$ and $\mathbf{Y}$ and the conformers with energy of less than $\mathbf{2}$ $\mathrm{kcal} / \mathrm{mol}$ were subjected to TDDFT calculations employing B3LYP, 6-31G basis in Gaussian09 software. The calculated ECD curves were compared to the experimental ECD for compound 2A (Figure 2). The experimental ECD curve gave a positive Cotton effect at 267 nm (+1.6) and negative Cotton effects at $219 \mathrm{~nm}(-3.9)$ and $304(-1.3)$ for compound 2A, confirming that it has the $\left(7 S, 8^{\prime} R\right)$ configuration. Compound 2 was identified as $\left(7 S, 8^{\prime} R\right)$ 3,3'-dimethoxy-4,4'-diacetoxy-7'-ketolignano-9,9'-lactone.

Compound 3, $\mathrm{C}_{17} \mathrm{H}_{16} \mathrm{O}_{6}$, gave the same molecular formula and NMR spectra as the homoisoflavonoid, 5,7-dihydroxy-3-(3-hydroxy-4-methoxybenzyl) chroman-4-one, isolated previously from Scilla kraussi and Muscari comosum. ${ }^{22}$ However, the specific rotation for this compound $\left([\alpha]_{D}{ }^{20}+5.1, \mathrm{CHCl}_{3}\right)$ did not agree with literature value $\left([\alpha]_{\mathrm{D}}{ }^{23.6}-51, \mathrm{CHCl}_{3}\right){ }^{22}$ so an ECD study was undertaken. The measured ECD spectrum showed Cotton effects of +1.54 at $290 \mathrm{~nm}$ and -0.9 at $240 \mathrm{~nm}$ for the unusual S-configuration. ${ }^{23}$ In all 
homoisoflavonoids reported from the Hyacinthoideae subfamily, where the configuration at C-3 has been determined, it has been reported as $R$, with the exception of only three homoisoflavonoids isolated by Nishida et al. ${ }^{24}$ from Barnardia japonica (Thunb.) Wijnands (investigated as Scilla scilloides (Lind.) Druce), which also showed the S-configuration, as determined by an ECD study. The unusual 3S-configuration has been reported once from the Urginiodeae subfamily, from Urginea depressa. ${ }^{25}$ The isolation of compound 3 was facilitated by acetylation yielding two products, the 3 '-acetate, (3A) and the 5,7-diacetate, (3B).

The ethanol extract of the bulbs of $R$. calcicola yielded two known bufadienolide glycosides, hellebrigenin-3-O- $\beta$-D-glucopyranoside (4) and gamabufotalin-3-O- $\alpha$-Lrhamnoside (5). The structures of the compounds were identified using NMR spectroscopy and confirmed by comparison against literature values. Hellebrigenin-3-O- $\beta$-Dglucopyranoside (4) has been isolated previously from Urginea altissima, ${ }^{26}$ Helleborus orientalis, and $H$. thibetanus (Ranunuclaceae). ${ }^{27,28}$ Gamabufotalin-3-O- $\alpha$-L-rhamnoside (5) has been isolated previously from Urginea altissima. ${ }^{29}$

The dichloromethane extract of the bulbs of Rhodocodon aff. intermedius yielded a complex mixture of homoisoflavonoids. Three new homoisoflavonoids, compounds 6-8 were isolated while the presence of further homoisoflavonoids, not containing any acetate groups, was clear from the NMR spectra of the mixtures. In order to facilitate separation of these complex mixtures of homoisoflavonoids, some of the initial fractions obtained via column chromatography were acetylated. Compounds 6A, 6B, and 7A were isolated as the acetylated products of compounds 6 and 7, respectively.

The ${ }^{1} \mathrm{H}$ NMR spectrum of compound 6 indicated it to be a benzylidene-type homoisoflavonoid $\left(\mathrm{H}_{2}-2\right.$ at $\delta_{\mathrm{H}} 5.32, \mathrm{~d}, J=2.5 \mathrm{~Hz} ; \mathrm{H}-9$ at $\left.\delta_{\mathrm{H}} 7.60, \mathrm{bs}\right){ }^{30}$ A single methoxy group was indicated by a three-proton resonance at $\delta_{H} 3.93$ (s). The B-ring was 3', 4'disubstituted $\left(\mathrm{H}-2^{\prime}, \delta_{\mathrm{H}} 6.87, \mathrm{~d}, J=1.5 \mathrm{~Hz} ; \mathrm{H}-5^{\prime}, \delta_{\mathrm{H}} 7.05, \mathrm{~d}, J=7.5 \mathrm{~Hz} ; \mathrm{H}-6^{\prime}, \delta_{\mathrm{H}} 6.91, \mathrm{dd}, J=7.5\right.$ $\mathrm{Hz}, 1.5 \mathrm{~Hz}$ ) and the methoxy group was placed at C-4' due to a correlation seen in the NOESY spectrum between the $\mathrm{H}-5^{\prime}$ and methoxy group proton resonances. A hydroxy group was placed at C-3'. An H-bonded hydroxy group was present at $\mathrm{C}-5\left(\delta_{H} 12.85, \mathrm{~s}\right)$ and the NOESY spectrum showed a correlation between this resonance and an additional hydroxy group resonance at $\delta_{\mathrm{H}} 9.45(\mathrm{~s})$, indicating the presence of an $\mathrm{OH}$ group at $\mathrm{C}-6$. The biosynthesis 
requires substitution at $\mathrm{C}-7$, in this case a hydroxy group. $\mathrm{H}-8$ was clearly visible as a single proton singlet at $\delta_{\mathrm{H}} 5.82$ and showed correlations in the $\mathrm{HMBC}$ spectrum with the C-4a $\left(\delta_{\mathrm{C}}\right.$ 102.64), C-6 $\left(\delta_{\mathrm{C}} 96.80\right), \mathrm{C}-7\left(\delta_{\mathrm{C}} 168.75\right)$, and C-8a $\left(\delta_{\mathrm{C}} 162.91\right)$ resonances. The geometry around the C-3/C-9 double bond was assigned as $E$, due to the correlation seen in the NOESY spectrum between the $\mathrm{H}_{2}-2$ and $\mathrm{H}-2^{\prime}$ resonances and the chemical shift of $\mathrm{H}-9$ at $\delta_{\mathrm{H}}$ 7.60. Z-geometry results in a lower chemical shift of approximately $\delta_{\mathrm{H}} 6.70-\delta_{\mathrm{H}} 7.07 .^{31}$ HRESIMS gave a peak at $\mathrm{m} / \mathrm{z}\left[\mathrm{M}^{+}-\mathrm{OCH}_{3}-\mathrm{OH}\right]$ of 281.0508 daltons for compound 6 . Two acetylated products of compound $\mathbf{6}$ were identified as the $7,3^{\prime}$-diacetate $\mathbf{6 A}$ and the $6,3^{\prime}$ diacetate 6B.

HRESIMS of compound 7 gave a $[\mathrm{M}-1]^{+}$ion at $\mathrm{m} / \mathrm{z}$ 313.0722, indicating a molecular formula of $\mathrm{C}_{17} \mathrm{H}_{13} \mathrm{O}_{6}$. Compound 7 was also structurally assigned as a benzylidene homoisoflavonoid $\left(\mathrm{H}_{2}-2, \delta_{\mathrm{H}} 5.24\right.$, bs; $\mathrm{H}-9, \delta_{\mathrm{H}} 7.69$, bs). The ${ }^{1} \mathrm{H}$ NMR spectrum indicated a $3^{\prime}, 4^{\prime}$-substituted B-ring with $\mathrm{H}-2^{\prime}$ at $\delta_{\mathrm{H}} 6.81, \mathrm{~d}(\mathrm{~J}=2.1 \mathrm{~Hz}), \mathrm{H}-5^{\prime} \delta_{\mathrm{H}} 6.85, \mathrm{~d}(\mathrm{~J}=8.1 \mathrm{~Hz})$ and $\mathrm{H}-$ $6^{\prime}$ at $\delta_{\mathrm{H}} 6.78, \mathrm{dd}(\mathrm{J}=8.1 \mathrm{~Hz}, 2.1 \mathrm{~Hz})$. A methoxy group $\left(\delta_{\mathrm{H}} 3.92\right)$ was placed at $\mathrm{C}-4^{\prime}$ due to a correlation seen with the $\mathrm{H}-5^{\prime}$ resonance in the NOESY spectrum. A hydroxy group was placed at $\mathrm{C}-3^{\prime}$ as in compound 6. A downfield singlet proton resonance found at $\delta_{\mathrm{H}} 12.70$ indicated the presence of a hydroxy group at C-5. A pair of meta-coupled peaks at $\delta_{\mathrm{H}} 5.93 \mathrm{~J}$ $=2.2 \mathrm{~Hz})$ and $\delta_{H} 5.84(\mathrm{~J}=2.2 \mathrm{~Hz})$ were assigned to $\mathrm{H}-6$ and $\mathrm{H}-8$, respectively, with the remaining hydroxy group, as indicated by the molecular formula, at C-7. The geometry around the C-3/C-9 double bond was assigned as $E$ due to the NOESY correlations seen between the $\mathrm{H}_{2}-2$ and $\mathrm{H}-2$ ' resonances and the chemical shift of $\mathrm{H}-9{ }^{31}$ Acetylation yielded the $3^{\prime}$-acetate, $7 \mathrm{~A}$.

Compound 8, a yellow powder, that has not been isolated previously from natural sources, was synthesized previously as the racemate. ${ }^{32}$ HRESIMS gave a $[\mathrm{M}+\mathrm{Na}]^{+}$peak at $m / z 369.0946$ indicating an elemental formula of $\mathrm{C}_{18} \mathrm{H}_{18} \mathrm{O}_{7}$ for this compound. Compound 8 was found to differ from the previous homoisoflavonoids isolated from $R$. aff. intermedius in that a benzyl group $\left(\mathrm{H}-3, \delta_{\mathrm{H}} 2.74, \mathrm{~m} ; \mathrm{H}-9 \beta, \delta_{\mathrm{H}} 3.16, \mathrm{dd}, J=13.2 \mathrm{~Hz}, 3.9 \mathrm{~Hz} ; \mathrm{H}-9 \alpha, \delta_{\mathrm{H}} 2.66, \mathrm{dd}\right.$, $J=13.2 \mathrm{~Hz}, 12.5 \mathrm{~Hz} ; \mathrm{H}-2 \alpha, \delta_{H} 4.25, \mathrm{dd}, J=10.9 \mathrm{~Hz}, 3.9 \mathrm{~Hz} ; \mathrm{H}-2 \beta, \delta_{\mathrm{H}} 4.09$, dd, $J=10.9 \mathrm{~Hz}, 12.5$ $\mathrm{Hz}$ ) was found at C-3 as opposed to a benzylidene group. The proton spectrum indicated the presence of two methoxy groups $\left(\delta_{H} 3.88\right.$ and $\left.\delta_{H} 3.94\right)$. As in compounds 6 and 7 , a $3^{\prime}, 4^{\prime}$-substitution pattern was present in ring B, and a NOESY correlation between one of the 
methoxy groups and the $\mathrm{H}-5^{\prime}$ resonance was used to place one of these at $\mathrm{C}-4^{\prime}$. The $\mathrm{HMBC}$ spectrum showed correlations between the $\mathrm{C}-4^{\prime}$ resonance and the $\mathrm{H}-2^{\prime}\left(\delta_{\mathrm{H}} 6.65\right), \mathrm{H}-6^{\prime}$ $\left(\delta_{\mathrm{H}} 6.60\right)$ and $\mathrm{H}-5^{\prime}\left(\delta_{\mathrm{H}} 6.79\right)$ resonances. A hydroxy group was placed at the remaining $\mathrm{C}-3^{\prime}$ position on ring $B$. The NOESY spectrum also showed a correlation between a hydroxy group proton resonance at $\delta_{\mathrm{H}} 8.90$ and the $\mathrm{C}-5$ hydroxy group proton resonance $\left(\delta_{\mathrm{H}} 12.23\right)$, so a further hydroxy group was placed at C-6. The C-7 $\left(\delta_{\mathrm{C}} 137.11\right)$ resonance showed a correlation with the methoxy group three-proton singlet and the $\mathrm{H}-8$ resonance in the HMBC spectrum. The ECD spectrum indicated a positive Cotton effect at $291 \mathrm{~nm}$ and as such the absolute configuration at $\mathrm{C}-3$ was assigned as $S(\mathrm{H}-\beta){ }^{23}$ This configuration appears to be characteristic of the Rhodocodon homoisoflavonoids, although not common among homoisoflavonoids.

Compounds 6 and 7A and the crude plant extracts were screened for COX-2 expression, and PGE-2 release. To gain some idea of their therapeutic potential, the effects of compounds 6 and 7A on COX-2 expression and activity (determined based on PGE-2 release from HCA-7 cells) was compared to that of aspirin, which has been demonstrated to reduce the incidence and also the mortality of colorectal cancer, ${ }^{33,34}$ and when at the concentration used in the present study ( $1 \mathrm{mM})$ has been shown to inhibit induced COX-2 expression in CRC cells in vitro. ${ }^{35}$ The western blotting results for the COX-2 expression experiments, showed that both compounds 6 and 7A slightly inhibited COX-2 expression compared to the untreated control by $10 \%(12 \mu \mathrm{M})$ and $8 \%(12 \mu \mathrm{M})$, respectively (Figures S1 and S2, Supporting Information), whereas aspirin (1 mM) inhibited COX-2 expression by $12 \%$. The DMSO control had no effect on expression (Figure S3, Supporting Information). The effect of whole plant extracts of plant material was investigated but for all concentrations tested (20 $\mu \mathrm{g} / \mathrm{mL}-9 \mathrm{mg} / \mathrm{mL}$ ) all cells were killed after a $48 \mathrm{~h}$ period of incubation so it was not possible to determine the effects of these extracts on COX-2 expression.

In tests for PGE-2 release from HCA-7 cells, some inhibition was seen ( $11 \%$ and $20 \%$ for compounds 7A and 6 , respectively, at $12 \mu \mathrm{M}$ ), the effect of compound 6 being statistically significant (Table 5). These results suggest that these compounds have a greater effect on COX-2 activity than expression. Aspirin (1 mM) inhibited PGE-2 release by $19 \%$ but DMSO showed no inhibition compared to the control (Table 5). For the reasons given above, it was not possible to determine the effect of the whole plant extracts on PGE-2 release. 
It is well established that some phenolic compounds, and plants rich in them, may possess anti-inflammatory activity via their inhibitory effect on a wide range of key inflammatory mediators, including COX-2. ${ }^{36-41}$ The effect of the homoisflavonoids 6 and $7 \mathbf{A}$ on COX-2 expression and activity is consistent with these findings and those of Waller et al. ${ }^{5}$ who reported that homoisoflavones from Ledebouria socialis and L. ovatifolia inhibited COX2 activity based on an in vitro assay. However, the findings of the present study suggest that in terms of their therapeutic potential, with regard to CRC cells, the target may be COX2 activity rather than its expression. When compared to the effect of aspirin (1 mM) on COX2 activity (as indicated by PGE- 2 release) the data suggest that at the concentrations used, compounds 6 and 7A at $12.5 \mu \mathrm{M}$ were as effective at inhibiting COX-2 activity as aspirin at a concentration of $1 \mathrm{mM}$. It is possible that at higher concentrations, especially for compound 6, which inhibited COX-2 activity by $20 \%$, compared to $19 \%$ for aspirin, the inhibitory effect would have been greater. However, it must be borne in mind that aspirin is not a selective COX-2 inhibitor ${ }^{16}$ and so for future studies a comparison of these and other homoisoflavanoids against a more appropriate inhibitor such as the NSAID celecoxib, which is considered by some to be clinically relevant in the treatment of colorectal cancer, is required. ${ }^{16,42}$

The effect of these compounds on CRC cells in vitro should not be limited to COX-2, as the development and progression of colorectal cancer occurs via several molecular mechanisms, ${ }^{43-46}$ and so future studies will be needed to further investigate and characterize the effect of these compounds on the growth of HCA-7, and other types of colorectal cancer cells to gain greater insight into their therapeutic potential.

\section{EXPERIMENTAL}

General Experimental Procedures. Optical rotations were recorded in $\mathrm{CHCl}_{3}$ on a $\mathrm{JASCO}$ P-1020 polarimeter (University of Surrey), the UV spectra were recorded using a Biochrom libraS60 in $\mathrm{MeOH}$ or acetonitrile in a $1 \mathrm{~cm}$ cell (University of Surrey), and the ECD spectra were recorded using a Chirascan spectropolarimeter at room temperature in a $1 \mathrm{~cm}$ cell in $\mathrm{MeOH}$ (University of Surrey). The IR spectra were recorded on a Perkin-Elmer 2000 spectrometer (University of Surrey). NMR spectra were recorded on a $500 \mathrm{MHz}$ Bruker AVANCE NMR instrument in either $\mathrm{CDCl}_{3}$ or $\mathrm{CD}_{3} \mathrm{OD}$ at room temperature. All chemical shifts ( $\delta)$ are in ppm and referenced to the relevant solvent references, $7.26 \mathrm{ppm}\left(\mathrm{CDCl}_{3}\right)$ and 4.87 ppm $\left(\mathrm{CD}_{3} \mathrm{OD}\right)$ for ${ }^{1} \mathrm{H}$ NMR spectra and $77.23 \mathrm{ppm}\left(\mathrm{CDCl}_{3}\right)$ and $49.15 \mathrm{ppm}\left(\mathrm{CD}_{3} \mathrm{OD}\right)$ for ${ }^{13} \mathrm{C}$ 
NMR spectra. ESIMS were either recorded on a Bruker MicroToF mass spectrometer using an Agilent $1100 \mathrm{HPLC}$ to introduce samples (University of Oxford; compounds 1, 3, 6, 6A, 7, 7A and 8) or a Micromass Quattro Ultima mass spectrometer using a Waters Alliance HPLC to introduce samples (University of Surrey; compounds 2A, 3A and 3B).

Plant Material. Rhodocodon bulbs, collected in Madagascar in collaboration with J. L. Andriantiana from the Parc Botanique et Zoologique de Tsimbazaza (Permit: XXX/13/MEF/SG/DGF/DCB.SAP/SCB (valid three months from 23/10/2013) Phyto for export: 1036/13/11-IV/RL/MAG), were cultivated and determined by one of us (W. K.). Voucher specimens have been retained at Karl-Franzens-University, Graz. Collection sites: Rhodocodon calcicola Knirsch, Mart.-Azorín \& Wetschnig (collection 04476: north of Mahajanga, collection 04480: a few km north east of the Mahajanga Forest Station), Rhodocodon campanulatus Knirsch, Mart-Azorín \& Wetschnig (collection 02446: south of Mahaboboka), Rhodocodon aff. intermedius Knirsch, Mart.-Azorín \& Wetschnig (collection 04474: south of Ankarana National Park; collection 05052: south of Ankarana, this collection differed from the type specimen by having longer filaments).

Extraction and Isolation. The bulbs of $R$. campanulatus $(0.4 \mathrm{~kg})$ and $R$. calcicola $(1.23 \mathrm{~kg})$ were chopped and successively extracted on a shaker for $24 \mathrm{~h}$ with ethanol, yielding extracts of $29.6 \mathrm{~g}$ and $75 \mathrm{~g}$, respectively. Separation of the extracts was carried out using column chromatography over silica gel (Merck art. 9385). Gradient elution was employed using a gradient starting with dichloromethane and methanol, where $304 \times 75 \mathrm{~mL}$ and $197 \times 75 \mathrm{~mL}$ fractions were collected for $R$. campanulatus and $R$. calcicola, respectively. Further separation of $R$. campanulatus over Sephadex LH-20 (Sigma Aldrich) using $1: 1 \mathrm{CH}_{2} \mathrm{Cl}_{2}$ and $\mathrm{MeOH}$, yielded 1 (50 mg) and purification over silica gel using column chromatography, compound $\mathbf{3}$ (10 mg). Acetylation of further fractions yielded 2A (10 mg), 3A (10 mg) and 3B (10 mg). Further separation of $R$. calcicola over Sephadex $\mathrm{LH}-20$ (with $\mathrm{CH}_{2} \mathrm{Cl}_{2}$ and $\mathrm{MeOH}$, 1:1) followed by preparative TLC (Macherey-Nagel Ref 818133, pre-coated TLC sheets Alugram SIL G/UV $254,88 \% \mathrm{CH}_{2} \mathrm{Cl}_{2}$ and $12 \% \mathrm{MeOH}$ ), yielded bufadienolides 4 (18 mg) and 5 (6 mg). A detailed separation protocol is shown in Schemes S1 and S2 (Supporting Information).

Rhodocodon aff. intermedius bulbs (1.25 kg) were chopped and successively extracted on a shaker for $24 \mathrm{~h}$ with dichloromethane and ethanol yielding extracts of $3.30 \mathrm{~g}$ and $58.3 \mathrm{~g}$, respectively. Initial separation of the dichloromethane extract using a Reveleris ${ }^{\circledR}$ iES flash 
chromatography system over silica gel and increasing solvent polarity from hexane, to hexane $/ \mathrm{CH}_{2} \mathrm{Cl}_{2}$, to $\mathrm{MeOH}$ yielded 115 fractions of $15 \mathrm{~mL}$ each. Further separation over silica gel using column chromatography (Merck 9385, 1:4:5 $\mathrm{MeOH}-$ hexane- $\mathrm{CH}_{2} \mathrm{Cl}_{2}$ ) yielded the homoisoflavonoids $6(5.6 \mathrm{mg}), 7(1.0 \mathrm{mg})$ and $8(4.1 \mathrm{mg})$. Acetylation of further fractions yielded 6A and 6B (4.4 mg) and 7A (5.4 mg).

3 $\beta$-(-O- $\beta$-D-Glucopyranosyl)-14 $\beta$-hydroxy-5 $\alpha$-19-oxobufa-20,22-dienolide (1): Yellow gum; $[\alpha]_{D}^{23.6}+320\left(c \mathrm{c} 0.1, \mathrm{CHCl}_{3}\right) ; \mathrm{IR}(\mathrm{NaCl}) v_{\max } 3419,2917,1732,1715 \mathrm{~cm}^{-1} ;{ }^{1} \mathrm{H} \mathrm{NMR}\left(\mathrm{CDCl}_{3}, 500\right.$ $\mathrm{MHz})$ and ${ }^{13} \mathrm{C} \mathrm{NMR}\left(\mathrm{CDCl}_{3}, 125 \mathrm{MHz}\right)$ are given in Table 1; HRESIMS $m / z 585.2675[\mathrm{M}+\mathrm{Na}]^{+}$ (calcd for $\mathrm{C}_{30} \mathrm{H}_{42} \mathrm{O}_{10} \mathrm{Na}, 585.2670$ )

(3S)-5,7-Dihydroxy-3S-(3'-hydroxy-4'-methoxybenzyl)-4-chromanone (3): White powder; $[\alpha]_{D}^{23.6}+5.2$ (c 0.6, $\left.\mathrm{CHCl}_{3}\right) ; \mathrm{ECD}(c 0.03, \mathrm{MeOH}) 291 \mathrm{~nm}(+1.54), 240 \mathrm{~nm}(-0.9) ; \mathrm{IR}(\mathrm{NaCl}) v_{\max }$

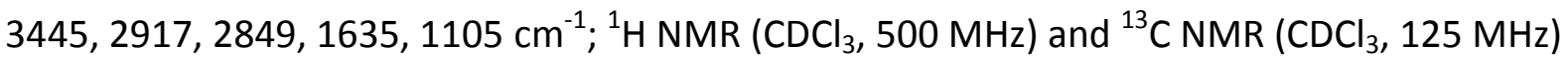
data are given in Tables 3 and 4; HRESIMS $\mathrm{m} / \mathrm{z} 315.0863[\mathrm{M}-\mathrm{H}]^{+}$(calcd for $\mathrm{C}_{17} \mathrm{H}_{15} \mathrm{O}_{6}$, 315.0874).

(E)-5,6,7-Trihydroxy-3-(3'-hydroxy-4'-methoxybenzylidene)-4-chromanone (6): Yellow gum; UV ( $\left.\mathrm{CH}_{3} \mathrm{CN}\right) \lambda_{\max }(\log \varepsilon) 258$ (3.59), 372 (3.92) nm; IR ( $\left.\mathrm{NaCl}\right) v_{\max } 3336,2961,2918$, $1732,1642,1593,1512,1259,1090,1027,798 \mathrm{~cm}^{-1} ;{ }^{1} \mathrm{H}$ NMR $\left(\mathrm{CDCl}_{3}, 500 \mathrm{MHz}\right)$ and ${ }^{13} \mathrm{C} \mathrm{NMR}$ $\left(\mathrm{CDCl}_{3}, 125 \mathrm{MHz}\right)$ data are given in Tables 3 and 4; HRESIMS m/z $281.0508\left[\mathrm{M}^{+}-\mathrm{OCH}_{3}-\mathrm{H}_{2} \mathrm{O}\right]$ (calcd for $\mathrm{C}_{17} \mathrm{H}_{14} \mathrm{O}_{7}, 330.0745, \mathrm{M}^{+}$not seen).

(E)-5,7-Dihydroxy-3-(3'-hydroxy-4'-methoxybenzylidene)-4-chromanone (7): Yellow gum; UV $\left(\mathrm{CH}_{3} \mathrm{OH}\right) \lambda_{\max }(\log \varepsilon) 273$ (3.87), 365 (3.85) nm; IR (NaCl) $v_{\max }$ 2958, 2929, 2859, 1727, 1579, 1462, 1380, 1274, 1123, $1072 \mathrm{~cm}^{-1} ;{ }^{1} \mathrm{H} \mathrm{NMR}\left(\mathrm{CDCl}_{3}, 500 \mathrm{MHz}\right)$ and ${ }^{13} \mathrm{C} \mathrm{NMR}\left(\mathrm{CDCl}_{3}\right.$, $125 \mathrm{MHz}$ ) data are given in Tables 3 and 4; HRESIMS m/z 313.0722 [M-1] (calcd for $\mathrm{C}_{17} \mathrm{H}_{13} \mathrm{O}_{6}$, 313.07176).

(3S)-5,6-Dihydroxy-7-methoxy-3-(3'-hydroxy-4'-methoxybenzyl)-4-chromanone (8): Yellow gum; $[\alpha]_{D}^{23.6}+29.4\left(\right.$ c 0.2, $\left.\mathrm{CHCl}_{3}\right)$; ECD (c $\left.3.6 \times 10^{-3}, \mathrm{MeOH}\right) 291 \mathrm{~nm}$ (+1.9), $253 \mathrm{~nm}(-0.7) ;$ UV $\left(\mathrm{CH}_{3} \mathrm{CN}\right) \lambda_{\max }(\log \varepsilon) 290$ (4.63), 338 (3.63) nm; IR (NaCl) $v_{\max }$ 3392, 2918, 1727, 1644, 1587, $1512,1469,1454,1274,1160,1101,1028,801,739 \mathrm{~cm}^{-1} ;{ }^{1} \mathrm{H} \mathrm{NMR}\left(\mathrm{CDCl}_{3}, 500 \mathrm{MHz}\right)$ and ${ }^{13} \mathrm{C}$ NMR $\left(\mathrm{CDCl}_{3}, 125 \mathrm{MHz}\right)$ data are given in Tables 3 and 4; HRESIMS m/z $369.0946[\mathrm{M}+\mathrm{Na}]^{+}$ (calcd for $\mathrm{C}_{18} \mathrm{H}_{18} \mathrm{O}_{7} \mathrm{Na}, 369.09477$ ). 
Acetylation Procedure. Compounds or fractions to be acetylated were dissolved in pyridine $(2 \mathrm{~mL})$ in a round-bottomed flask, acetic anhydride $(2 \mathrm{~mL})$ was added, and the reaction was left to stand overnight. Methanol $(10 \mathrm{~mL})$ was added to the reaction mixture to remove unreacted acetic anhydride. Toluene $(4 \times 10 \mathrm{~mL})$ was added in order to remove the pyridine, and was removed using a rotary evaporator. Thereafter, methanol $(5 \times 10 \mathrm{~mL})$ was added and evaporated off to remove the remaining toluene. The fractions were subjected to column chromatography over silica gel (Merck 9385, 4:1 ether-hexane) to yield 3A then preparative TLC was used to yield 2A and 3B (Scheme S1, Supplementary Information). Column chromatography over silica gel (Merck 9385, 1:4:5, MeOH-HexaneDCM) yielded 7A and a mixture of 6 A and $6 B$.

3,3'-Dimethoxy-4,4'-diacetoxy-7'-ketolignano-9,9'-lactone (2A): White powder; $[\alpha]_{D}{ }^{23.6}$ +5.1 (c 0.5, $\mathrm{CHCl}_{3}$ ); ECD (c 0.02, MeOH) $267 \mathrm{~nm}(+1.6), 219 \mathrm{~nm}(-3.9), 304$ (-1.3); IR ( $\left.\mathrm{NaCl}\right)$ $v_{\max } 3445,2918,2849,1769,1508,1267,1158 \mathrm{~cm}^{-1} ;{ }^{1} \mathrm{H} \mathrm{NMR}\left(\mathrm{CDCl}_{3}, 500 \mathrm{MHz}\right)$ and ${ }^{13} \mathrm{C} \mathrm{NMR}$ $\left(\mathrm{CDCl}_{3}, 125 \mathrm{MHz}\right)$ data are given in Table 2; HRESIMS m/z $479.1253[\mathrm{M}+\mathrm{Na}]^{+}$(calcd for $\left.\mathrm{C}_{24} \mathrm{H}_{24} \mathrm{O}_{9}, 479.1318\right)$.

(3S)-5,7-Dihydroxy-3S-(3'-acetoxy-4'-methoxybenzyl)-4-chromanone (3A): White powder; $[\alpha]_{D}^{23.6}+4.6$ (c 0.39, $\mathrm{CHCl}_{3}$ ); ECD (c 0.04, MeOH) $290 \mathrm{~nm}(+0.5), 235 \mathrm{~nm}(-0.2) ; \mathrm{IR}(\mathrm{NaCl}) v_{\max }$

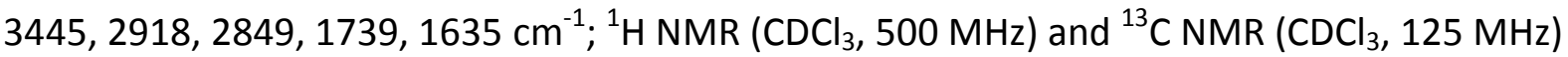
data are given in Tables 3 and 4.; HRESIMS $m / z 381.0941[\mathrm{M}+\mathrm{Na}]^{+}$(calcd for $\mathrm{C}_{19} \mathrm{H}_{18} \mathrm{O} \mathrm{O}_{7} \mathrm{Na}$, 381.0951).

(3S)-5,7-Diacetoxy-3S-(3'-hydroxy-4'-methoxybenzyl)-4-chromanone (3B): White powder; $[\alpha]_{D}^{23.6}+5.1$ (c 7.0, $\left.\mathrm{CHCl}_{3}\right) ; \mathrm{ECD}(c \mathrm{c} 0.03, \mathrm{MeOH}) 278 \mathrm{~nm}(+0.7), 238 \mathrm{~nm}(-1.8) ; \mathrm{IR}(\mathrm{NaCl}) v_{\max }$ 3444, 2916, 2848, 1738, 1766, 1618, $1158 \mathrm{~cm}^{-1} ;{ }^{1} \mathrm{H} \mathrm{NMR}\left(\mathrm{CDCl}_{3}, 500 \mathrm{MHz}\right)$ and ${ }^{13} \mathrm{C} \mathrm{NMR}$ $\left(\mathrm{CDCl}_{3}, 125 \mathrm{MHz}\right.$ ) data are given in Tables 3 and 4; HRESIMS m/z $423.0999[\mathrm{M}+\mathrm{Na}]^{+}$(calcd for $\mathrm{C}_{21} \mathrm{H}_{20} \mathrm{O}_{8} \mathrm{Na}$, 423.1056).

(E)-7-Acetoxy-5-hydroxy-3-(3'-hydroxy-4'-methoxybenzylidene)-4-chromanone (7A): Yellow gum; UV $\left(\mathrm{CH}_{3} \mathrm{CN}\right) \lambda_{\max }(\log \varepsilon) 365$ (4.09) nm; IR (NaCl) $v_{\max } 3364,2962,2927,1767$, $1732,1644,1634,1592,1511,1469,1445,1366,1261,1160,1026,811 \mathrm{~cm}^{-1} ;{ }^{1} \mathrm{H}$ NMR $\left(\mathrm{CDCl}_{3}, 500 \mathrm{MHz}\right)$ and ${ }^{13} \mathrm{C} \mathrm{NMR}\left(\mathrm{CDCl}_{3}, 125 \mathrm{MHz}\right)$ data are given in Tables 3 and 4; HRESIMS $m / z 379.0788[\mathrm{M}+\mathrm{Na}]^{+}$(calcd for $\mathrm{C}_{19} \mathrm{H}_{16} \mathrm{O}_{7} \mathrm{Na}, 379.07882$ ). 
COX-2 Expression and PGE-2 Release. For COX-2 expression tests, HCA-7 cells obtained by Sigma-Aldrich, UK from Culture Collections Public Health England, UK (www.PHECulturecollections.org.uk/) were seeded into 6-well plates (Nunclone Delta, Fisher, UK) with Dulbecco's modified Eagle's medium (DMEM) (Sigma-Aldrich, UK, D5796 $500 \mathrm{~mL}$ ) in 10\% fetal bovine serum (FBS) (Sigma-Aldrich, UK F7524) and incubated at $37{ }^{\circ} \mathrm{C}$ and $5 \% \mathrm{CO}_{2}$. After 48 h, when cells were almost $80 \%$ confluent, each whole plant extract (in \% DMSO) (20 $\mu \mathrm{g} / \mathrm{mL}-9 \mathrm{mg} / \mathrm{mL})$ or homoisoflavonoid compounds 6 and 7A $(12.5 \mu \mathrm{M})$ in 100\% DMSO was added and left for another $48 \mathrm{~h}$. Controls were also set up and were "no treatment" (cell culture medium only), a DMSO control (HCA-7 cells in $0.3 \%$ DMSO) and a positive control (1 mM aspirin, (Sigma-Aldrich, UK A5376-100 g). Compounds 6 and 7A were selected for this part of the investigation as the amounts in DMSO were known. After the second $48 \mathrm{~h}$ incubation, cells were lysed using LDS NuPAGE lysis buffer (Fisher, UK 10718414) and the western blotting was performed using equal amounts of sample (lysed cells) based on protein content, $(30 \mu \mathrm{g})$.

PGE-2 is a product of COX-2 and thus PGE-2 release by cells expressing COX-2 is commonly used as a marker of COX-2 activity, ${ }^{16}$ thus the effect of compounds 6 and $7 \mathbf{A}$ on PGE-2 release by HCA-7 cells was investigated. HCA-7 cells were seeded and incubated as described above. After the second $48 \mathrm{~h}$ period, the cell culture medium was collected and stored at $-20^{\circ} \mathrm{C}$. For the PGE-2 assay, the samples were defrosted, centrifuged at $1000 \mathrm{rpm}$ for $4 \mathrm{~min}$, and then assayed using a PGE-2 ELISA kit, according to the manufacturer's instructions (RND Systems, UK KGE004B). This assay is based on the forward sequential competitive binding technique in which PGE2 present in a sample competes with horseradish peroxidase (HRP)-labelled PGE2 for a limited number of binding sites on a mouse monoclonal antibody. PGE2 in the sample is allowed to bind to the antibody in the first incubation. During the second incubation, HRP-labelled PGE2 binds to the remaining antibody sites. Following a wash to remove unbound materials, a substrate solution is added to the wells to determine the bound enzyme activity. The color development was stopped, and the absorbance was read at $450 \mathrm{~nm}$. The intensity of the color is inversely proportional to the concentration of PGE2 in the sample. 
Supporting Information. Copies of spectra for all new compounds and isolation flow charts for each plant species

\section{AUTHOR INFORMATION}

Corresponding Author. *Tel: +44 2087146634. E-mail: s.schwikkard@kingston.ac.uk ACKNOWLEDGEMENTS. Sianne Schwikkard would like to gratefully acknowledge support from the Daphne Jackson Trust and the Royal Society of Chemistry as well as assistance from Dr. Julian Swindon for the running of some of the HRMS and Dr. Jean-Marie Peron for providing access to the NMR facility at Kingston University. 


\section{REFERENCES}

(1) Knirsch, W.; Martínez-Azorín, M.; Pfosser, M.; Wetschnig, W. Phytotaxa 2015, 195, 101-134.

(2) Pfosser, M.; Wetschnig, W.; Speta, F. Linzer Biologische Beiträge 2006, 38, 1731-1739.

(3) Pfosser, M.; Knirsch, W.; Pinter, M.; Ali, A.; Dutta, S.; Wetschnig, W. Plant Ecol. Evol. 2012, 145, 65-72.

(4) Della Loggia, R.; Del Negro, P.; Tubaro, A.; Barone, G.; Parrilli, M. Planta Med. 1989, 55, 587-588.

(5) Waller, C. P.; Thumser, A. E.; Langat, M. K.; Crouch, N. R.; Mulholland, D. A. Phytochemistry 2013, 95, 284-290.

(6) Aggarwal, B. B.; Shishodia, S.; Sandur, S. K.; Pandey, M. K.; Sethi, G. Biochem. Pharmacol. 2006, 72, 1605-1621.

(7) Brown, J. R.; DuBois, N. J. Clin. Oncol. 2005, 23, 2840-2855.

(8) Eberhart, C. E.; Coffey, R. J.; Radhika, A.; Giardiello, F. M.; Ferrenbach, S.; DuBois, R. N. Gastroenterology 1994, 107, 1183-1188.

(9) Soslow, R. A.; Dannenberg, A. J.; Rush, D.; Woerner, B. M.; Khan, K. N.; Masferrer, J.; Koki, A. T. Cancer 2000, 89, 2637-2645.

(10) Wang, M.-T.; Honn, K. V.; Nie, D. Cancer Metast. Rev. 2007, 26, 525-534.

(11) Wiese, F. W.; Thompson, P. A.; Warneke, J.; Einspahr, J.; Alberts, D. S.; Kadlubar, F. F.

Mol. Carcinog. 2003, 37, 25-31.

(12) Ferlay, J.; Shin, H.-R.; Bray, F.; Forman, D.; Mathers, C.; Parkin, D. M. Int. J. Cancer 2010, 127, 2893-2917.

(13) Jemal, A.; Siegel, R.; Xu, J.; Ward, E. CA Cancer J. Clin. 2010, 60, 277-300.

(14) Ogino, S.; Kirkner, G. J.; Nosho, K.; Irahara, N.; Kure, S.; Shima, K.; Hazra, A.; Chan, A. T.; Dehari, R.; Giovannucci, E. L.; Fuchs, C. S. Clin. Cancer Res. 2008, 14, 8221-8227.

(15) Sheehan, K. M.; Sheahan, K.; O'Donoghue, D. P.; MacSweeney, F.; Conroy, R. M., Fitzgerald, D. J.; Murray, F. E. JAMA 1999, 282, 1254-1257.

(16) Greenborough, A.; Smartt, H. J. M.; Moore, A. Roberts, H. R.; Williams, A. C.; Parakeva, C.; Kaidi, A. Carcinogenesis 2009, 30, 377-386.

(17) Koorbanally C.; Mulholland, D. A. Crouch, N.R. Biochem. System. Ecol. 2006, 34, 588592.

(18) Mulholland, D. A.; Schwikkard, S. L.; Crouch, N. R. Nat. Prod. Rep. 2013, 30, 1153-1266.

(19) Nogawa, T.; Kamano, Y.; Yamashita, A.; Pettit, G. R. J. Nat. Prod. 2004, 67, 1960-1960.

(20) Agrawal, P. K. Phytochemistry 1992, 31, 3307-3330.

(21) Silverstein, R. M.; Webster, F. X. Spectrometric Identification of Organic Compounds; 6th ed.; Wiley: New York, 1998, p482.

(22) Adinolfi, M.; Barone, G.; Belardini, M.; Lanzetta, R.; Laonigro, G.; Parrilli, M.

Phytochemistry 1985, 24, 2423-2426.

(23) Adinolfi, M.; Barone, G.; Corsaro, M. M.; Mangoni, L.; Lanzetta, R.; Parrilli, M. Tetrahedron 1988, 44, 4981-4988.

(24) Nishida, Y.; Eto, M.; Miyashita, H.; Ikeda, T.; Yamaguchi, K.; Yoshimitsu, H.; Nohara, T.; Ono, M. Chem. Pharm. Bull. 2008, 56, 1022-1025.

(25) Dai, Y.; Harinantenaina, L.; Brodie, P.; Goetz, M.; Young, S.; Dyk, K. T.; Kingston, D.G. I. J. Nat. Prod. 2013, 76, 865-872.

(26) Shimada, K.; Umezawa, E.; Nambara, T.; Kupchan, S. M. Chem. Pharm. Bull. 1979, 27, 3111-3114.

(27) Watanabe, K.; Mimaki, Y.; Sakagami, H.; Sashida, Y. J. Nat. Prod. 2003, 66, 236-241. 
(28) Yang, F.-Y.; Su, Y.-F.; Wang, Y.; Chai, X.; Han, X.; Wu, Z.-H.; Gao, X.-M. Biochem. System. Ecol. 2010, 38, 759-763.

(29) Dagne, E.; Mammo, W.; Alemu, M.; Casser, I. Bull. Chem. Soc. Ethiopia 1994, 8, 85-89.

(30) Masterova, I.; Suchy, V.; Uhrin, D.; Ubik, K.; Grancaiova, Z.; Bobovnicky, B.

Phytochemistry 1991, 30, 713-714.

(31) Siddaiah, V.; Rao, C. V.; Venkateswarlu, S.; Krishnaraju, A. V.; Subbaraju, G. V. Bioorg. Med. Chem. 2006, 14, 2545-2551.

(32) Lee, B.; Basavarajappa, H. D.; Sulaiman, R. S.; Fei, X.; Seo, S.-Y.; Corson, T. W. Org. Biomol. Chem. 2014, 12, 7673-7677.

(33) Giovannucci, E.; Rimm, E. B.; Stampfer, M. J.; Colditz, G. A.; Ascherio, A.; Willett, W. C. Ann. Intern. Med. 1994, 121, 241-246.

(34) Thun, M.; Namboodiri, M.; Heath, C. N. Engl. J. Med. 1991, 325, 1593-1596.

(35) Shtivelband, M. L.; Juneja, H. S.; Lee, S.; Wu, K. K. J. Throm. Haemost. 2003, 1, 22252233.

(36) Baker, I.; Chohan, M.; Opara, E. Plant Foods Hum. Nutr. 2013, 68, 364-369.

(37) Chohan, M.; Naughton, D.; Jones, L.; Opara, E. Oxid. Med. Cell. Long. 2012, 2012, 1942-1951.

(38) Goel, A.; Boland, C. R.; Chauhan, D. P. Cancer Lett. 2001, 172, 111-118.

(39) Li, F.; Nitteranon, V.; Tang, X.; Liang, J.; Zhang, G.; Parkin, K. L.; Hub, Q. Food Chem. 2012, 135, 332-337.

(40) Mueller, M.; Hobiger, S.; Jungbauer, A. Food Chem. 2010, 122, 987-996.

(41) Van Breemen, R. B.; Tao, Y.; Li, W. Fitoterapia 2011, 82, 38-43.

(42) Rahman, M.; Selvarajan, K.; Hasan, M. R.; Chan, A. P.; Jin, C.; Kim, J.; Chan, S. K.; Le, N. D.; Kim, Y.-B. Neoplasia 2012, 14, 624-633.

(43) Tachibana, M.; Kawamata, H.; Fujimori, T.; Omotehara, F.; Horiuchi, H.; Ohkura, Y.; Kubota, K. Int. J. Oncol. 2004, 25, 913-920.

(44) Fearon, E. R. Ann. Rev. Pathol.: Mechan. Disease 2011, 6, 479-507.

(45) Muzny, D. M.; Bainbridge, M. N.; Chang, K.; Dinh, H. H.; Drummond, J. A.; Fowler, G.; Newsham, I. F. Nature 2012, 487, 330-337.

(46) Valkenburg, K. C.; Graveel, C. R.; Zylstra-Diegel, C. R.; Zhong, Z.; Williams, B. O. Cancer 2011, 3, 2050-2079. 
Table 1. ${ }^{1} \mathrm{H}$ NMR $\left(500 \mathrm{MHz}\right.$ ) and ${ }^{13} \mathrm{C}$ NMR (125 MHz) Data for Compound 1 (in $\mathrm{CD}_{3} \mathrm{OD}$ )

\begin{tabular}{|c|c|c|c|}
\hline position & $\delta_{c}$ & $\delta_{\mathrm{H}}(\mathrm{J}$ in $\mathrm{Hz})$ & $\mathrm{HMBC}(\mathrm{H} \rightarrow \mathrm{C})$ \\
\hline $1 \alpha$ & $32.3, \mathrm{CH}_{2}$ & $1.06, \mathrm{~m}$ & $2,3,5,10$ \\
\hline $1 \beta$ & & $2.45, \mathrm{~m}$ & $2,9,19,10$ \\
\hline $2 \alpha$ & $31.7, \mathrm{CH}_{2}$ & $1.34, \mathrm{~m}$ & 3,10 \\
\hline $2 \beta$ & & $2.02, \mathrm{~m}$ & - \\
\hline $3 \alpha$ & 78.6, $\mathrm{CH}$ & $3.79, \mathrm{~m}$ & $1^{\prime}$ \\
\hline $4 \alpha$ & $36.9, \mathrm{CH}_{2}$ & $1.32, \mathrm{~m}^{a}$ & 5 \\
\hline $4 \beta$ & & $1.96, \mathrm{~m}$ & - \\
\hline $5 \alpha$ & $44.2, \mathrm{CH}$ & $1.42, \mathrm{~m}$ & 9 \\
\hline $6 \alpha$ & $28.9, \mathrm{CH}_{2}$ & $2.30, \mathrm{~m}$ & 5,10 \\
\hline $6 \beta$ & & $2.17, \mathrm{~m}$ & - \\
\hline $7 \alpha$ & $23.3, \mathrm{CH}_{2}$ & $1.23, \mathrm{~m}$ & - \\
\hline $7 \beta$ & & $1.72, \mathrm{~m}$ & 9,14 \\
\hline $8 \beta$ & $44.4, \mathrm{CH}$ & $1.64, \mathrm{~m}$ & - \\
\hline $9 \alpha$ & $50.0, \mathrm{CH}$ & $1.31, \mathrm{~m}^{a}$ & 5,10 \\
\hline 10 & $53.0, \mathrm{C}$ & - & - \\
\hline $11 \alpha$ & $32.7, \mathrm{CH}_{2}$ & $1.69, \mathrm{~m}$ & - \\
\hline $11 \beta$ & & $2.02, \mathrm{~m}$ & - \\
\hline $12 \alpha$ & $41.5, \mathrm{CH}_{2}$ & $1.41, \mathrm{~m}$ & 13 \\
\hline $12 \beta$ & & $1.53, \mathrm{~m}$ & 13 \\
\hline 13 & $49.8, C$ & - & - \\
\hline 14 & $85.6, \mathrm{C}$ & - & - \\
\hline $15 \alpha$ & $32.7, \mathrm{CH}_{2}$ & $1.69, \mathrm{~m}$ & 13,16 \\
\hline $15 \beta$ & & $2.02, \mathrm{~m}$ & - \\
\hline $16 \alpha$ & $29.8, \mathrm{CH}_{2}$ & $2.19, \mathrm{~m}$ & $13,14,15,20$ \\
\hline $16 \beta$ & & $1.67, \mathrm{~m}$ & - \\
\hline $17 \alpha$ & $52.2, \mathrm{CH}$ & $2.56, \mathrm{dd}(6.4,9.5)$ & $12,13,14,16,20,21$ \\
\hline 18 & $17.2, \mathrm{CH}_{3}$ & $0.68, s$ & $12,13,14,17$ \\
\hline 19 & 210.6, CH & $10.02, \mathrm{~s}$ & $1,5,10$ \\
\hline 20 & $125.0, \mathrm{C}$ & - & - \\
\hline 21 & $150.7, \mathrm{CH}$ & $7.47, \mathrm{dd}(0.9,2.5)$ & $17,21,24$ \\
\hline 22 & $149.4, \mathrm{CH}$ & $8.01, \mathrm{dd}(2.5,9.7)$ & $17,21,24$ \\
\hline 23 & $115.6, \mathrm{CH}$ & $6.29, \mathrm{dd}(0.9,9.7)$ & 17,24 \\
\hline 24 & $164.9, \mathrm{C}$ & - & - \\
\hline $1^{\prime}$ & $102.5, \mathrm{CH}$ & $4.41, \mathrm{~d}(7.8)$ & 3 \\
\hline $2^{\prime}$ & $72.2, \mathrm{CH}$ & $3.14, \mathrm{dd}(7.8,9.0)$ & $1^{\prime}, 3^{\prime}$ \\
\hline $3^{\prime}$ & $78.2, \mathrm{CH}$ & $3.36, \mathrm{dd}(9.0,9.5)$ & $2^{\prime}, 4^{\prime}$ \\
\hline $4^{\prime}$ & $71.8, \mathrm{CH}$ & $3.26, \mathrm{dd}(9.5,9.6)$ & $5^{\prime}, 6^{\prime}$ \\
\hline $5^{\prime}$ & $78.1, \mathrm{CH}$ & $3.23, \mathrm{dd}(9.6,5.4)$ & - \\
\hline $6^{\prime}{ }_{A}$ & $63.0, \mathrm{CH}_{2}$ & $3.87, \mathrm{dd}(1.0,11.6)$ & $4^{\prime}$ \\
\hline $6^{\prime}{ }_{B}$ & & $3.66, \mathrm{dd}(5.4,11.6)$ & $3^{\prime}, 4^{\prime}$ \\
\hline
\end{tabular}

${ }^{a}$ Overlapped proton resonances. 
Table 2. ${ }^{1} \mathrm{H}$ NMR (500 MHz) and ${ }^{13} \mathrm{C}$ NMR (125 MHz) Data for Compound $2 \mathrm{~A}$ (in $\mathrm{CDCl}_{3}$ )

\begin{tabular}{llll}
\hline position & $\delta_{\mathrm{C}}$ type & $\delta_{\mathrm{H}}(\mathrm{J}$ in $\mathrm{Hz})$ & $\mathrm{HMBC}(\mathrm{H} \rightarrow \mathrm{C})$ \\
\hline 1 & $136.1, \mathrm{C}$ & - & - \\
2 & $113.5, \mathrm{CH}$ & $6.71, \mathrm{~d}(1.9)$ & 1,4 \\
3 & $151.5, \mathrm{C}$ & - & - \\
4 & $139.0, \mathrm{C}$ & - & - \\
5 & $123.3, \mathrm{CH}$ & $6.87, \mathrm{~d}(8.1)$ & $1,3,4$ \\
6 & $121.6, \mathrm{CH}$ & $6.64, \mathrm{dd}(1.9,8.1)$ & 1,2 \\
$7 \beta$ & $44.5, \mathrm{CH}$ & $3.56, \mathrm{dt}(6.1,9.1)$ & $1,9,7^{\prime}$ \\
8 & $34.6, \mathrm{CH}$ & $3.07, \mathrm{~d}(6.1)$ & $1,2,7,8^{\prime}, 9$ \\
9 & $176.9, \mathrm{C}$ & - & - \\
$1^{\prime}$ & $134.4, \mathrm{C}$ & - & - \\
$2^{\prime}$ & $111.9, \mathrm{CH}$ & $7.43, \mathrm{~d}(1.9)$ & $3^{\prime}, 4^{\prime}, 6^{\prime}, 7^{\prime}$ \\
$3^{\prime}$ & $152.2, \mathrm{C}$ & - & - \\
$4^{\prime}$ & $145.2, \mathrm{C}$ & - & - \\
$5^{\prime}$ & $123.2, \mathrm{CH}$ & $7.10, \mathrm{~d}(8.1)$ & $1^{\prime}, 3^{\prime}, 4^{\prime}$ \\
$6^{\prime}$ & $121.7, \mathrm{CH}$ & $7.20, \mathrm{dd}(8.1,1.9)$ & $2^{\prime}, 4^{\prime}, 7^{\prime}$ \\
$7^{\prime}$ & $195.4, \mathrm{C}$ & - & - \\
$8^{\prime} \alpha$ & $47.2, \mathrm{CH}$ & $4.07, \mathrm{dt}(9.1,16.7)$ & $7^{\prime}, 9^{\prime}$ \\
$9^{\prime} \alpha$ & $68.2, \mathrm{CH}_{2}$ & $4.44, \mathrm{t}(9.1)$ & 7,9 \\
$9^{\prime} \beta$ & & $4.11, \mathrm{t}(9.1)$ & 7,9 \\
OMe-3 & $55.9, \mathrm{CH}_{3}$ & $3.66, \mathrm{~s}$ & 3 \\
OMe -3' & $56.3, \mathrm{CH}_{3}$ & $3.87, \mathrm{~s}$ & $3^{\prime}$ \\
OAc -4 & $20.9, \mathrm{CH}_{3}$ & $2.29, \mathrm{~s}$ & $\mathrm{OAc}^{\prime}-4$ \\
OAc -4 & $169.1, \mathrm{C}$ & - & - \\
OAc -4' & $20.9, \mathrm{CH}_{3}$ & $2.33, \mathrm{~s}$ & - \\
OAc -4 & $168.5, \mathrm{C}$ & - & \\
\hline
\end{tabular}


Table 3. ${ }^{1} \mathrm{H}$ NMR (500 MHz) Data for Compounds 3, 3A, 3B, 6, 7, 7A and 8 (in $\mathrm{CDCl}_{3}, \mathrm{~J}$ in $\mathrm{Hz}$ )

\begin{tabular}{|c|c|c|c|c|c|c|c|}
\hline position & 3 & $3 A$ & 3B & 6 & 7 & $7 \mathrm{~A}$ & 8 \\
\hline 2 & $\begin{array}{l}\text { 4.27, dd }(4.3,11.5) 4.11, \mathrm{dd} \\
(7.5,11.5)\end{array}$ & $\begin{array}{l}4.29, \mathrm{dd}(4.5,11.5) \\
4.11, \mathrm{dd}(7.5,11.5)\end{array}$ & $\begin{array}{l}4.31, \text { dd }(4.5,11.5) \\
4.14, \text { dd }(7.5,11.5)\end{array}$ & $5.32, d(2.5)$ & 5.24, bs & $5.21, d(1.8)$ & $\begin{array}{l}4.25, \mathrm{dd}(10.9,3.9) ; 4.09, \mathrm{dd} \\
(10.9,12.5)\end{array}$ \\
\hline 3 & $2.82, \mathrm{~m}$ & $2.81, \mathrm{~m}$ & $2.72, \mathrm{~m}$ & & & & $2.74, \mathrm{~m}$ \\
\hline $\mathrm{OH}-5$ & $12.13, \mathrm{~s}$ & $12.09, \mathrm{~s}$ & & $12.85, \mathrm{~s}$ & $12.70, \mathrm{~s}$ & $12.64, \mathrm{~s}$ & $12.23, \mathrm{~s}$ \\
\hline 6 & $5.97, d(2.0)$ & $5.98, d(2.2)$ & $6.81, d(2.2)$ & & $5.93, d(2.2)$ & $5.92, d(2.2)$ & \\
\hline $\mathrm{OH}-6$ & & & & $9.45, \mathrm{~s}$ & & & $8.90, \mathrm{~s}$ \\
\hline $\mathrm{OH}-7$ & $5.29, \mathrm{~s}$ & $5.29, \mathrm{~s}$ & & & & & \\
\hline 8 & $5.91, d(2.0)$ & $5.91, d(2.2)$ & $6.27, d(2.2)$ & $5.82, \mathrm{~s}$ & $5.84, \mathrm{~d}(2.2)$ & $5.81, \mathrm{~d}(2.2)$ & $5.91, \mathrm{~s}$ \\
\hline \multirow[t]{2}{*}{9} & $2.65, \mathrm{dd}(10.4,13.9)$ & $2.69, \mathrm{dd}(10.4,13.9)$ & $2.58, \mathrm{dd}(10.7,14.0)$ & 7.60, bs & 7.69, bs & 7.68, bs & 2.66 , dd $(12.5,13.2) ; 3.16$, dd \\
\hline & $3.15, \mathrm{dd}(4.6,13.9)$ & $3.16, \mathrm{dd}(4.6,13.9)$ & $3.15, \mathrm{dd}(4.2,14.0)$ & & & & $(13.2,3.9)$ \\
\hline $2^{\prime}$ & 6.81, bs & $6.91, \mathrm{~d}(2.2)$ & $6.87, \mathrm{~d}(2.2)$ & $6.87, d(1.5)$ & $6.81, d(2.1)$ & $6.92, d(2.1)$ & $6.65, d(2.0)$ \\
\hline $\mathrm{OH}-3^{\prime}$ & $5.59, \mathrm{~s}$ & & $5.59, \mathrm{~s}$ & & & & \\
\hline $5^{\prime}$ & $6.80, d J=8.1$ & $6.92, d(8.4)$ & $6.91, d(8.4)$ & $7.05, \mathrm{~d} J=7.5$ & $6.85, d(8.1)$ & $6.94, d(8.5)$ & $6.79, \mathrm{~d}(8.3)$ \\
\hline $6^{\prime}$ & $6.71, \mathrm{brd} J=8.1$ & $7.05, \mathrm{dd}(2.2,8.4)$ & $7.02, \mathrm{dd}(8.4,2.2)$ & $\begin{array}{l}6.91, \mathrm{dd} J=1.5 \\
7.5\end{array}$ & $6.78, d_{1}(8.1,2.1)$ & $7.10, \mathrm{dd}(8.5,2.1)$ & $6.60, \mathrm{dd}(8.3,2.0)$ \\
\hline $\mathrm{OCH}_{3}$ & $3.88, \mathrm{~s}$ & $3.82, \mathrm{~s}$ & $3.81, \mathrm{~s}$ & $3.93, \mathrm{~s}$ & $3.92, \mathrm{~s}$ & $3.80, \mathrm{~s}$ & $3.88, \mathrm{~s}$ \\
\hline $\mathrm{OCH}_{3}$ & & & & & & & $3.94, \mathrm{~s}$ \\
\hline OAc-3' & & $2.31, \mathrm{~s}$ & & & & $2.26, \mathrm{~s}$ & \\
\hline OAc-7 & & & $2.39, \mathrm{~s}$ & & & & \\
\hline OAC-5 & & & $2.3,1 \mathrm{~s}$ & & & & \\
\hline
\end{tabular}


Table 4. ${ }^{13} \mathrm{C}$ NMR (125 MHz) Data for Compounds 3, 3A, 3B, 6, 7, 7A and 8 (in $\mathrm{CDCl}_{3}$ )

\begin{tabular}{|c|c|c|c|c|c|c|c|}
\hline position & 3 & $3 A$ & $3 B$ & 6 & 7 & $7 \mathrm{~A}$ & 8 \\
\hline 2 & 69.1, $\mathrm{CH}_{2}$ & $69.1, \mathrm{CH}_{2}$ & 69.4, $\mathrm{CH}_{2}$ & $67.50, \mathrm{CH}_{2}$ & \multirow[t]{5}{*}{$67.45, \mathrm{CH}_{2}$} & $67.59, \mathrm{CH}_{2}$ & $69.77, \mathrm{CH}_{2}$ \\
\hline 3 & $46.7, \mathrm{CH}$ & $46.9, \mathrm{CH}$ & $48.3, \mathrm{CH}$ & $127.38, \mathrm{C}$ & & $125.26, \mathrm{C}$ & $47.03, \mathrm{CH}$ \\
\hline 4 & 197.9, C & $200.3, \mathrm{C}$ & 190.9, C & 185.49, C & & 184.76, C & 207.14, C \\
\hline $4 a$ & 102.8, C & 102.9, C & 102.6, C & 102.64, C & & 104.22, C & 108.19, C \\
\hline 5 & 163.7, C & 163.4, C & 152.9, C & 165.15, C & & $163.75, C$ & 163.37, C \\
\hline 6 & 96.6, $\mathrm{CH}$ & 96.9, CH & 105.6, CH & $96.80, C$ & \multirow[t]{2}{*}{$96.79, \mathrm{CH}$} & $96.84, C$ & $110.85, \mathrm{C}$ \\
\hline 7 & 164.0, C & 164.4, C & $150.6, \mathrm{C}$ & $168.75, C$ & & $165.50, \mathrm{C}$ & 137.11, C \\
\hline 8 & 94.9, CH & $95.3, \mathrm{CH}$ & 101.7, CH & $94.52, \mathrm{CH}$ & \multirow[t]{2}{*}{$95.05, \mathrm{CH}$} & $95.37, \mathrm{CH}$ & $94.45, \mathrm{CH}$ \\
\hline $8 a$ & 164.9, C & 164.9, C & $164.3, \mathrm{C}$ & $162.91, \mathrm{C}$ & & $163.75, \mathrm{C}$ & 166.87, C \\
\hline 9 & $32.2, \mathrm{CH}_{2}$ & $32.0, \mathrm{CH}_{2}$ & 31.7, $\mathrm{CH}_{2}$ & $136.84, \mathrm{CH}$ & \multirow[t]{2}{*}{$137.32, \mathrm{CH}$} & 136.12, CH & $32.74, \mathrm{CH}_{2}$ \\
\hline $1^{\prime}$ & 131.4, C & 131.0, C & 131.0, C & $123.78, \mathrm{C}$ & & $130.49, \mathrm{C}$ & $126.60, \mathrm{C}$ \\
\hline $2^{\prime}$ & $115.2, \mathrm{CH}$ & $112.9, \mathrm{CH}$ & 123.9, CH & $111.87, \mathrm{CH}$ & \multirow[t]{3}{*}{$115.94, \mathrm{CH}$} & $124.91, \mathrm{CH}$ & $111.35, \mathrm{CH}$ \\
\hline $3^{\prime}$ & $145.8, \mathrm{C}$ & $150.6, \mathrm{C}$ & 152.7, C & $146.72, \mathrm{C}$ & & $139.24, C$ & $138.80, \mathrm{C}$ \\
\hline $4^{\prime}$ & 145.5, C & $150.2, \mathrm{C}$ & 150.1, C & $150.31, \mathrm{C}$ & & 151.49, C & $154.62, \mathrm{C}$ \\
\hline $5^{\prime}$ & 111.0, CH & $123.8, \mathrm{CH}$ & $112.9, \mathrm{CH}$ & 122.59, CH & $110.62, \mathrm{CH}$ & 112.66, $\mathrm{CH}$ & $116.54, \mathrm{CH}$ \\
\hline $6^{\prime}$ & $120.4, \mathrm{CH}$ & $127.6, \mathrm{CH}$ & 127.6, CH & 116.74, CH & $123.59, \mathrm{CH}$ & 129.95, CH & $121.74, \mathrm{CH}$ \\
\hline $\mathrm{OCH}_{3}$ & $56.0, \mathrm{CH}_{3}$ & $56.2, \mathrm{CH}_{3}$ & $56.4, \mathrm{CH}_{3}$ & $56.12, \mathrm{CH}_{3}$ & \multirow[t]{6}{*}{$56.06, \mathrm{CH}_{3}$} & $56.17, \mathrm{CH}_{3}$ & $56.13, \mathrm{CH}_{3}$ \\
\hline $\mathrm{OCH}_{3}$ & & & & & & & $61.97, \mathrm{CH}_{3}$ \\
\hline \multirow[t]{2}{*}{ OAC } & & $20.9, \mathrm{CH}_{3}$ & $21.4, \mathrm{CH}_{3}$ & & & 20.67, $\mathrm{CH}_{3}$ & \\
\hline & & $168.2, \mathrm{C}$ & $169.8, \mathrm{C}$ & & & 169.00, C & \\
\hline \multirow[t]{2}{*}{ OAC } & & & $20.9, \mathrm{CH}_{3}$ & & & & \\
\hline & & & $169.3, \mathrm{C}$ & & & & \\
\hline
\end{tabular}


Table 5. The Effects of Compounds 6 and 7A on PGE2 Release from HCA7 Cells

\begin{tabular}{|c|c|c|c|}
\hline compound & PGE2 $(\mathrm{pg} / \mathrm{ml})(\mathrm{n}=3)$ & $\mathrm{SD}( \pm)$ & $\%$ inhibition (\%) \\
\hline control/no treatment & 3800 & 330 & \\
\hline compound 6 & 3026 & $170^{c}$ & $20^{a}$ \\
\hline compound 7A & 3384 & $164^{c}$ & $11^{a}$ \\
\hline aspirin (1 mM) & 3074 & $152^{c}$ & $19^{a}$ \\
\hline DMSO $\quad(0.3 \%)^{b}$ & 4013 & 119 & no inhibition $^{d}$ \\
\hline
\end{tabular}

${ }^{a}$ In comparison to control; mean \pm SD $\mathrm{n}=3$ representing three separate experiments, samples run in duplicate. ${ }^{b}$ Vehicle control. ${ }^{c}$ Statistically significant difference $(p<0.05)$ in comparison to the control/no treatment. For statistical analysis One-way ANOVA with post hoc LSD test was performed. ${ }^{d}$ PGE- 2 release greater than the control by $6 \%$; mean \pm SD $n=1$, sample run in duplicate. 
<smiles>[R6]c1ccc([C@@H]2CC(=O)OC[C@H]2C(=O)c2ccc(OC)c(OC)c2)cc1OC</smiles><smiles>[R20]Oc1cc(C[C@@H]2COc3cc(OC)c([R2])c([2H])c3C2=O)ccc1OC</smiles>

$3 \mathrm{R}_{1}=\mathrm{R}_{2}=\mathrm{R}_{3}=\mathrm{R}_{4}=\mathrm{H}$ $3 A R_{1}=R_{2}=R_{3}=H, R_{4}=A C$ 3B $R_{1}=A c, R_{2}=H, R_{3}=A c, R_{4}=H$ $8 \mathrm{R}_{1}=\mathrm{CH}_{3}, \mathrm{R}_{2}=\mathrm{OH}, \mathrm{R}_{3}=\mathrm{R}_{4}=\mathrm{H}$

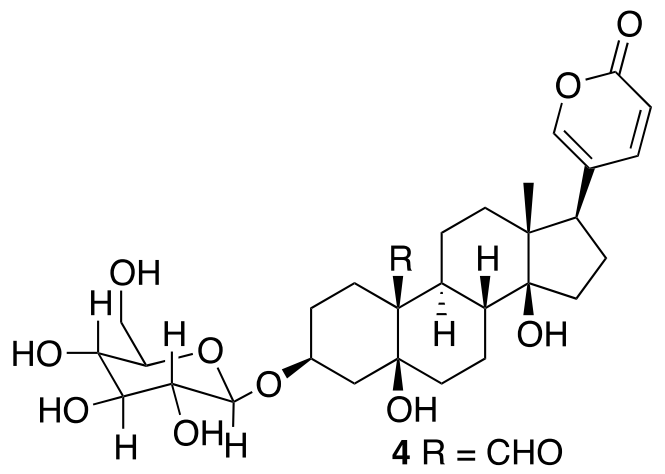<smiles>[R6]c1cc2c(c([R])c1O)C(=O)C(=Cc1ccc(OC)c(OC)c1)CO2</smiles>

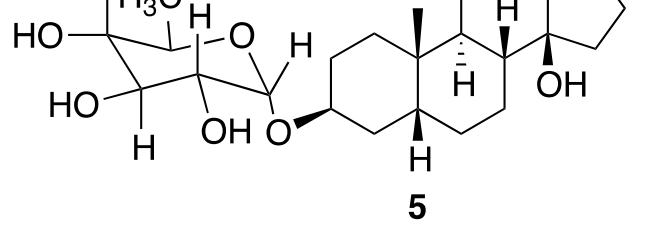

$6 \mathrm{R}_{1}=\mathrm{H}, \mathrm{R}_{2}=\mathrm{OH}, \mathrm{R}_{3}=\mathrm{H}$ $6 A R_{1}=A c, R_{2}=O H, R_{3}=A c$ $6 B R_{1}=H, R_{2}=O A c, R_{3}=A c$ $7 \mathrm{R}_{1}=\mathrm{R}_{2}=\mathrm{R}_{3}=\mathrm{H}$

7A $R_{1}=R_{2}=H, R_{3}=A C$

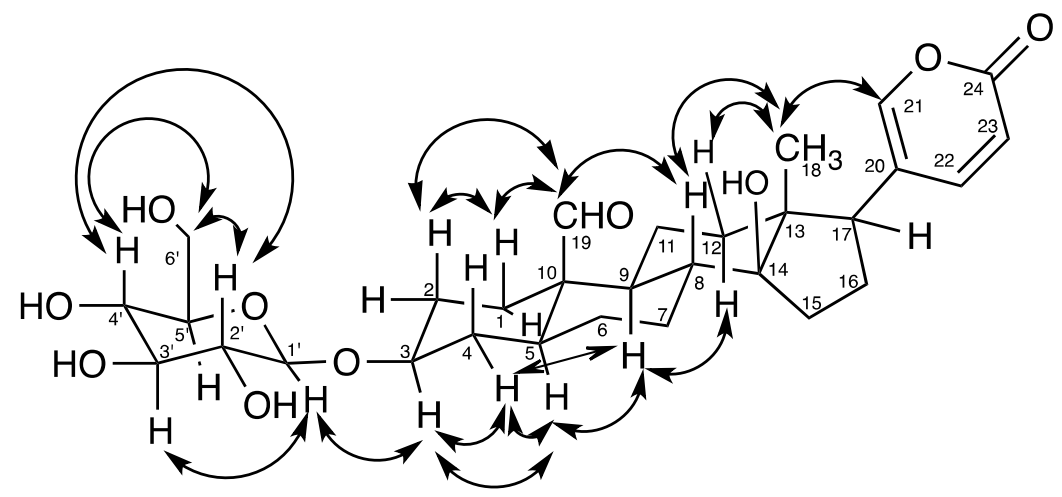

Figure 1. Selected NOESY correlations for compound 1 


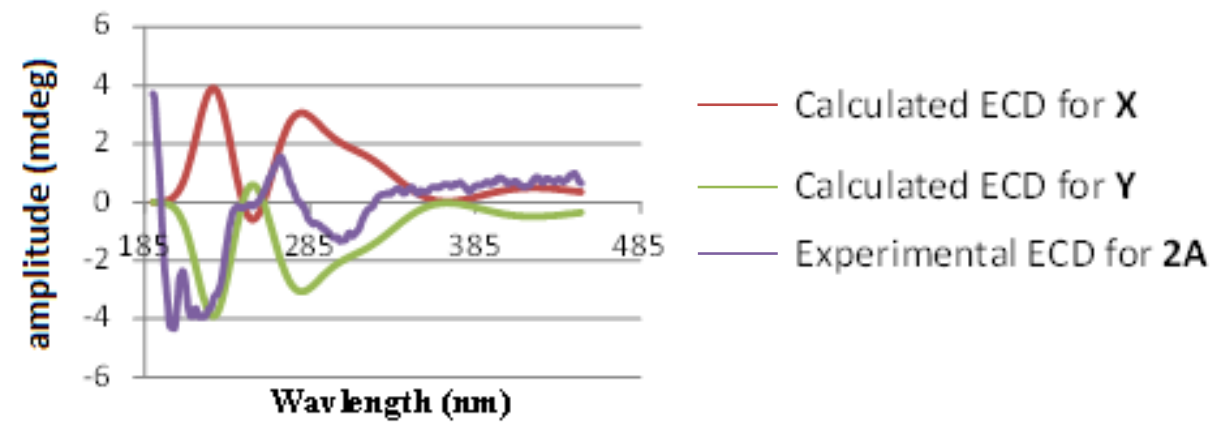

Figure 2. Modelled and experimental ECD spectra of compound 2A 
Table of Contents/Abstract Graphic

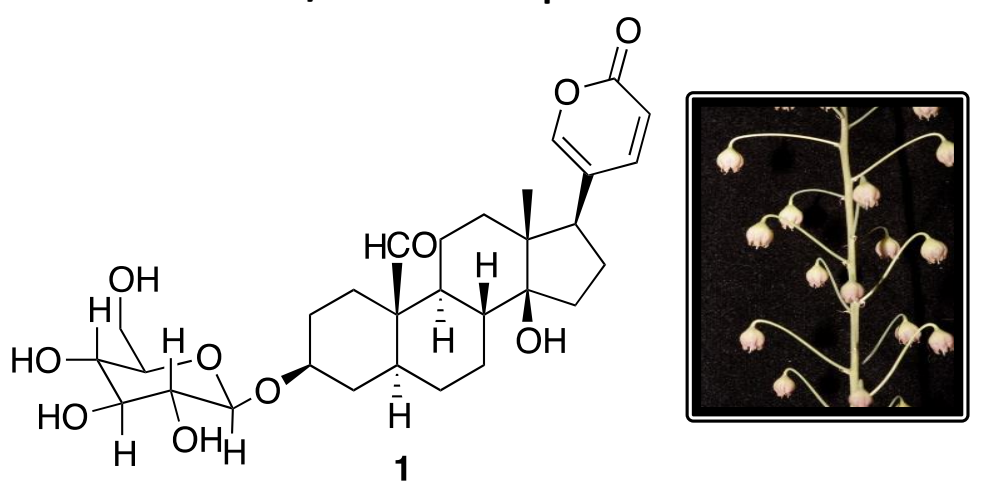


Phytochemical Investigations of Three Rhodocodon (Hyacinthaceae șSensu APG II) Species.

Sianne Schwikkard, ${ }^{*}+{ }^{\dagger}$ Alaa Alqahtani, ${ }^{\dagger}$ Walter Knirsch, ${ }^{\S}$ Wolfgang Wetschnig, ${ }^{\S}$ Andrius Jaksevicius, ${ }^{\ddagger}$ Elizabeth I Opara, ${ }^{\ddagger}$ Moses K Langat, ${ }^{\dagger,}$ Jackie L. Andriantiana," and Dulcie A Mulholland ${ }^{\dagger,}$

${ }^{\dagger}$ Natural Products Research Group, Department of Chemistry, Faculty of Engineering and Physical Sciences, University of Surrey, Guildford, GU2 7XH, United Kingdom

${ }^{\ddagger}$ School of Life Sciences, Pharmacy and Chemistry, Faculty of Science, Engineering and Computing, Kingston University, Penrhyn Road, Kingston Upon Thames, KT1 2EE, United Kingdom

§Institute of Plant Sciences, NAWI Graz, Karl-Franzens-University Graz, Holteigasse 6, A-8010, Graz, Austria

${ }^{\perp}$ School of Chemistry and Physics, University of KwaZulu-Natal, Durban, 4041, South Africa

"Parc Botanique et Zoologique de Tsimbazaza, Rue Kasanga Fernand, Antananarivo 101, Madagascar

*Tel: +44 2087146634, email: s.schwikkard@kingston.ac.uk 
Contents

S1: Flow charts showing how compounds were isolated

S2: ${ }^{1} \mathrm{H}$ and ${ }^{13} \mathrm{C}$ NMR spectra for the new compounds

S3: Figures S1 - S3 


\section{S1: Flow charts showing isolation of compounds}

Figure 1S: Flow chart showing how compounds were isolated from Rhodocodon campulatus.

LC- large column-silica or sephedex- $5 \mathrm{~cm}$ diameter, $75 \mathrm{ml}$ fractions collected

SC-Sephedex- small column sephedex, $1 \mathrm{~cm}$ diameter, $2 \mathrm{ml}$ fraction collectedSC-Silica- small column Silica,

$1 \mathrm{~cm}$ diameter, $2 \mathrm{ml}$ fraction collected

PTLC- preparative TLC

D- dichlorome

Rhodocodon

E-ether

H-hexane

F- fraction

Ethanol

extraget 446
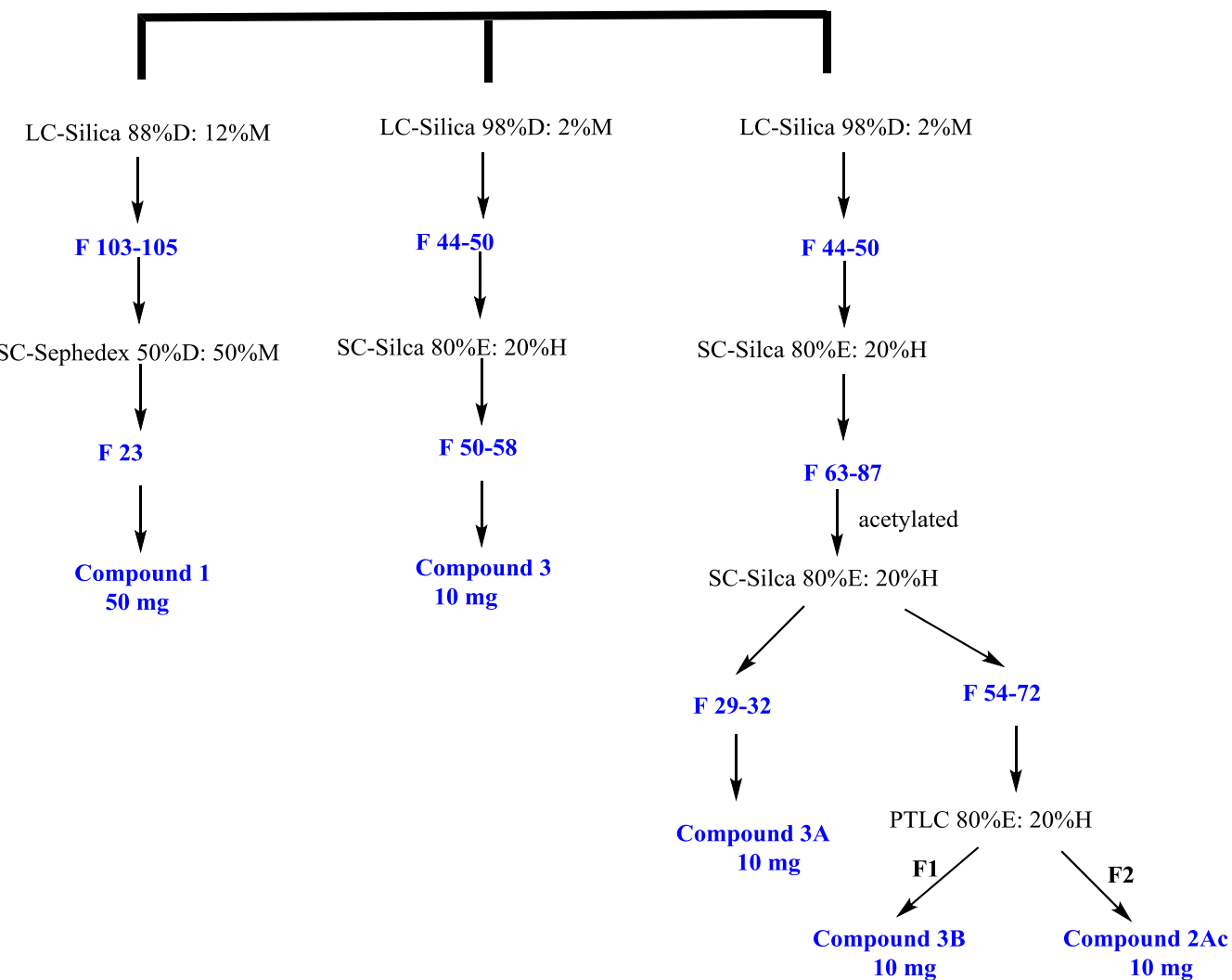
Figure 2S: Flow chart showing how compounds were isolated from Rhodocodon calcicola

LC- large column-silica or sephedex- $5 \mathrm{~cm}$ diameter, $75 \mathrm{ml}$ fractions collected SC-Sephedex- small column sephedex , $1 \mathrm{~cm}$ diameter, $2 \mathrm{ml}$ fraction collected PTLC- preparative TLC Rhodocodon calcicola
D- dichloromethane M- methanol Ethanol extract

F- fraction $\downarrow$

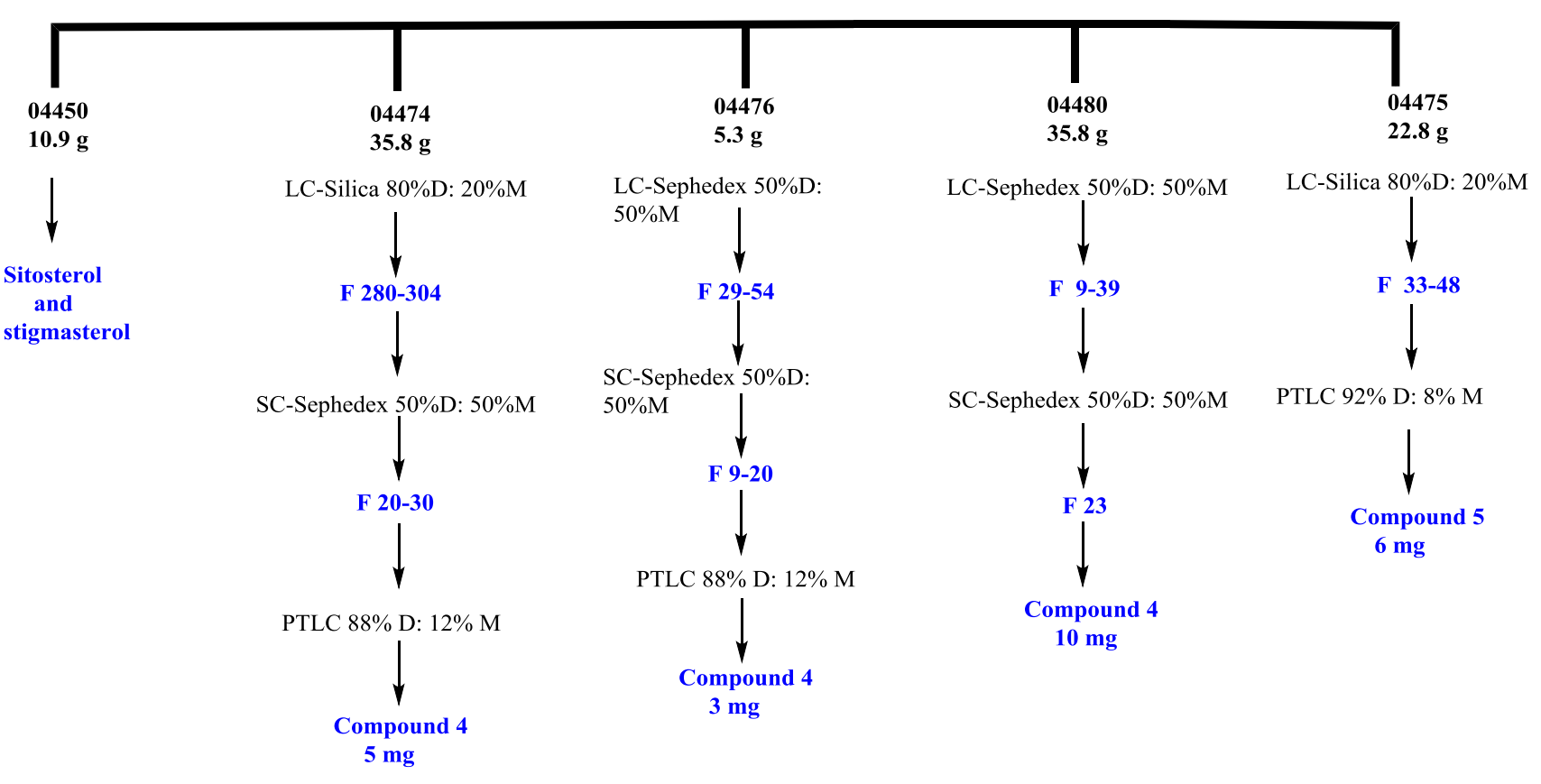


Figure 3S: Flow chart showing how compounds were isolated from Rhodocodon aff. intermedius

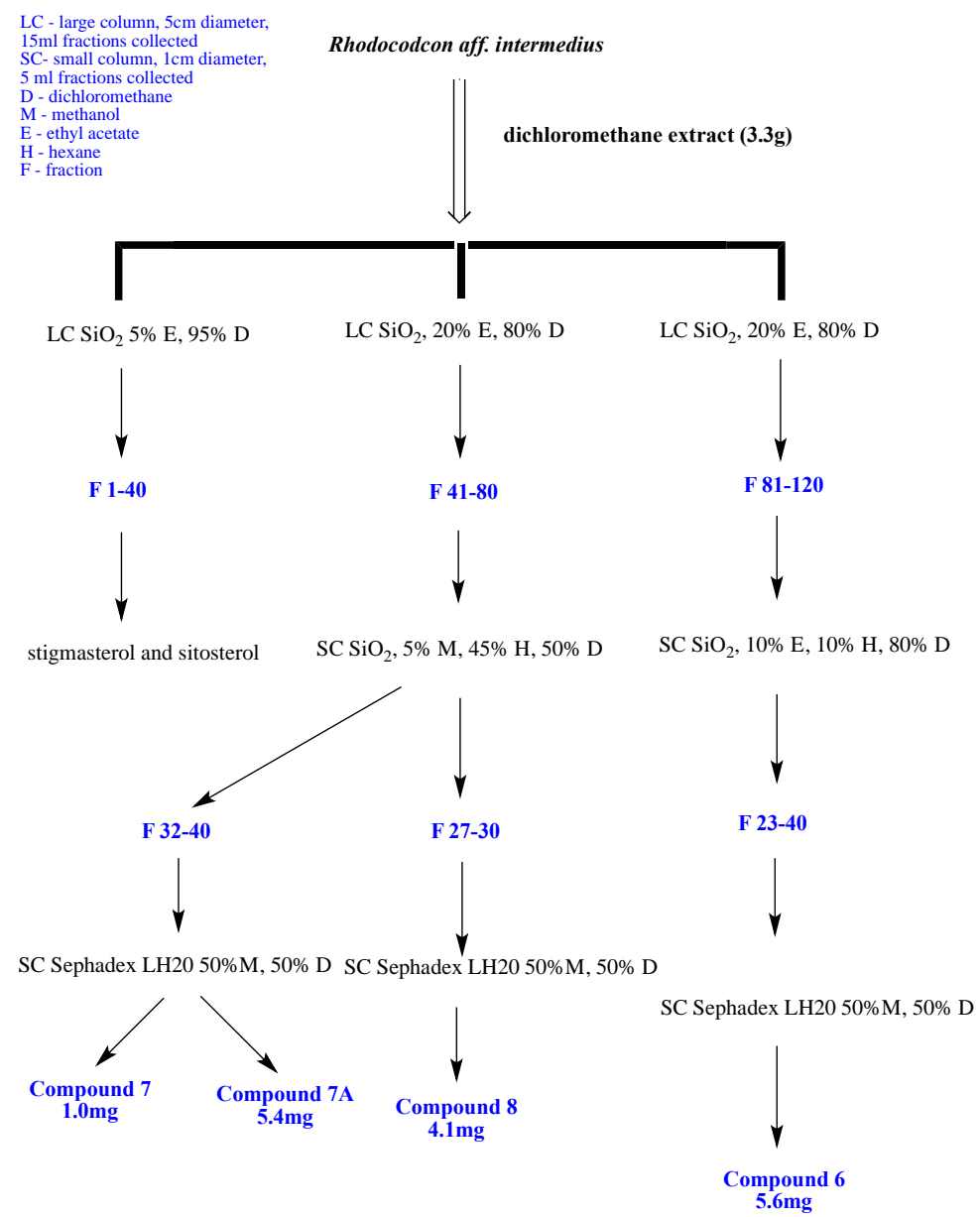


S2: ${ }^{1} \mathrm{H}$ and ${ }^{13} \mathrm{C}$ NMR spectra for the isolated compounds

${ }^{1}$ H NMR spectrum for compound 1

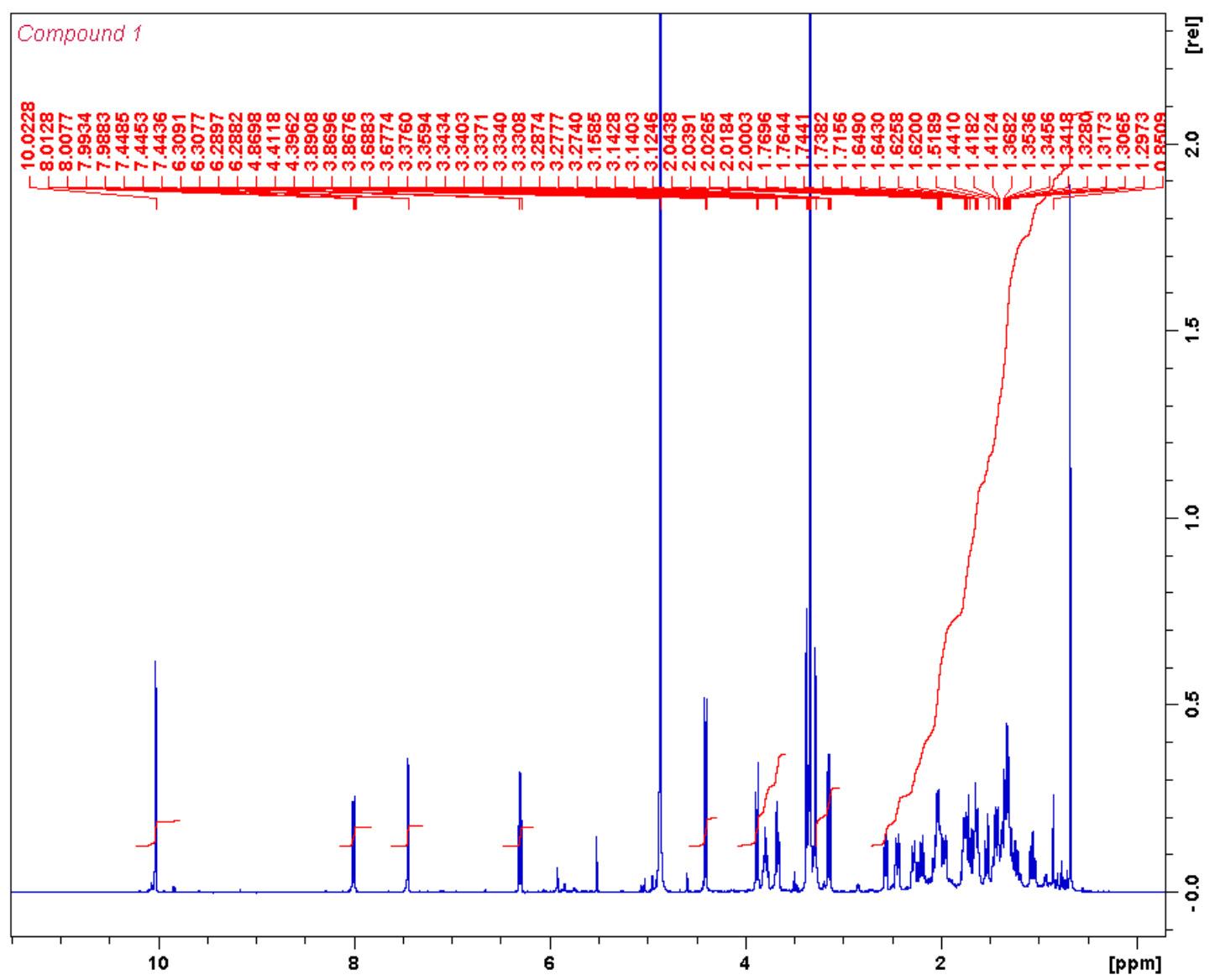


${ }^{13} \mathrm{C}$ NMR spectrum for compound 1

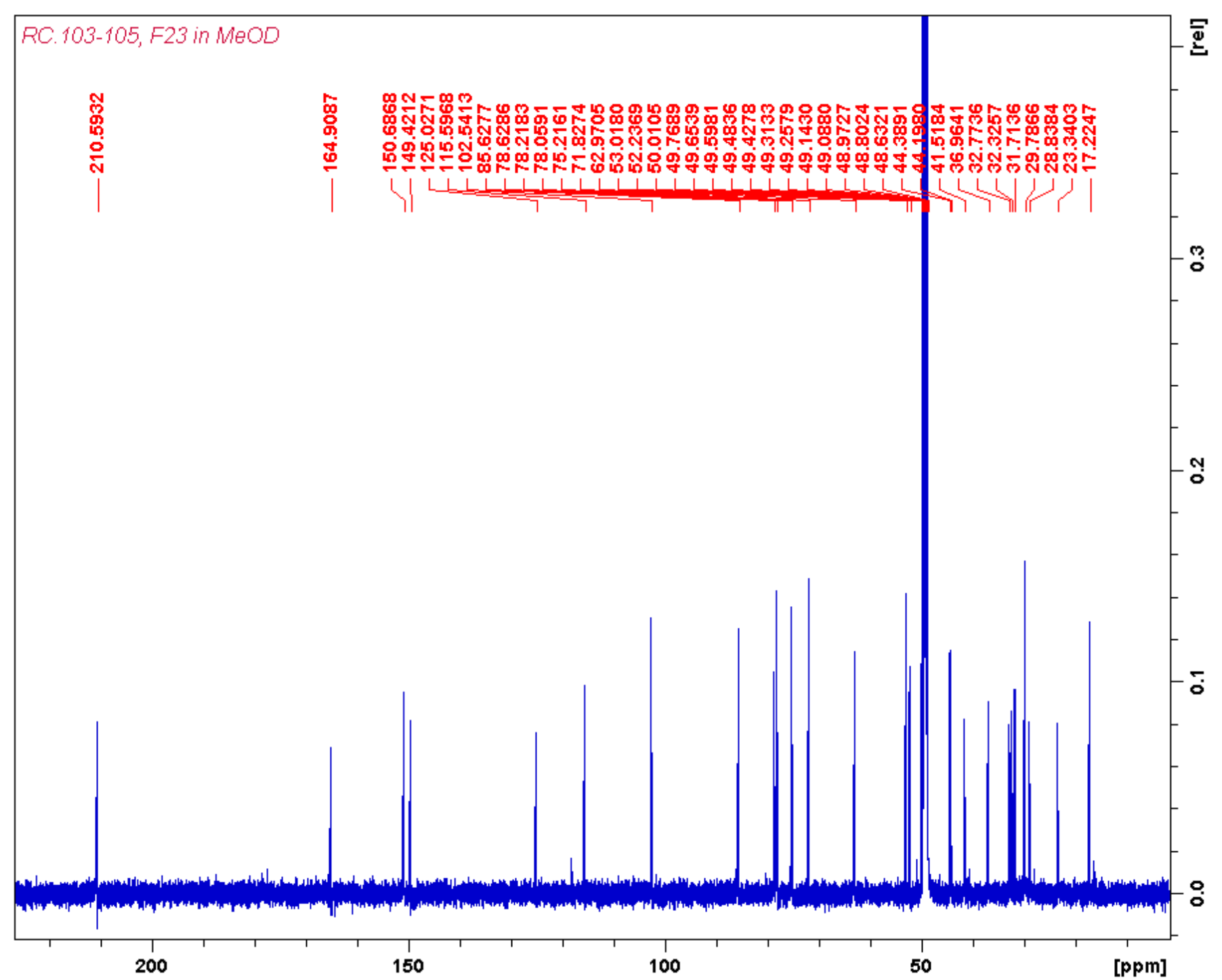


${ }^{1} \mathrm{H}$ NMR compound for $2 \mathrm{~A}$

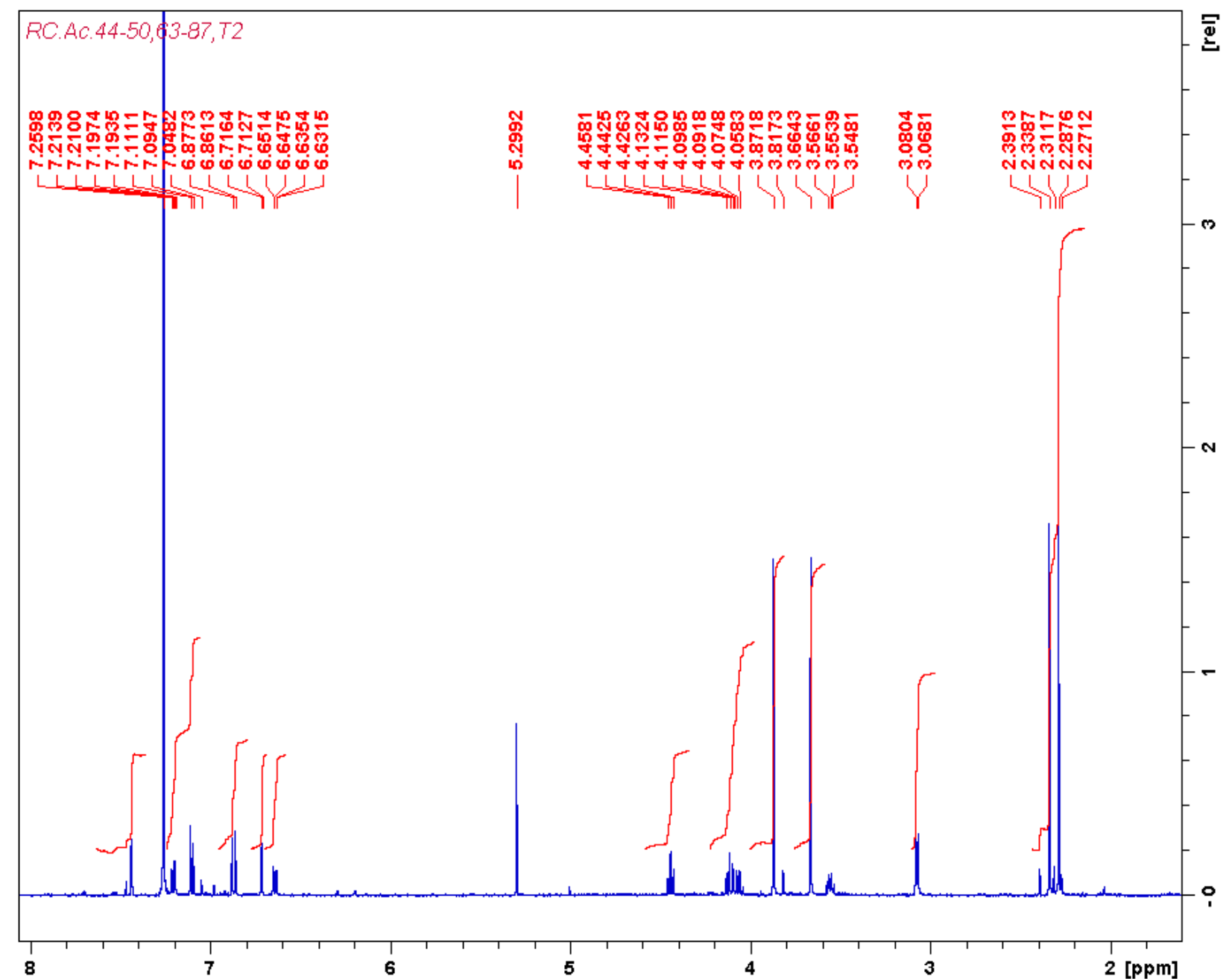


${ }^{13} \mathrm{C}$ NMR spectrum for $2 \mathrm{~A}$

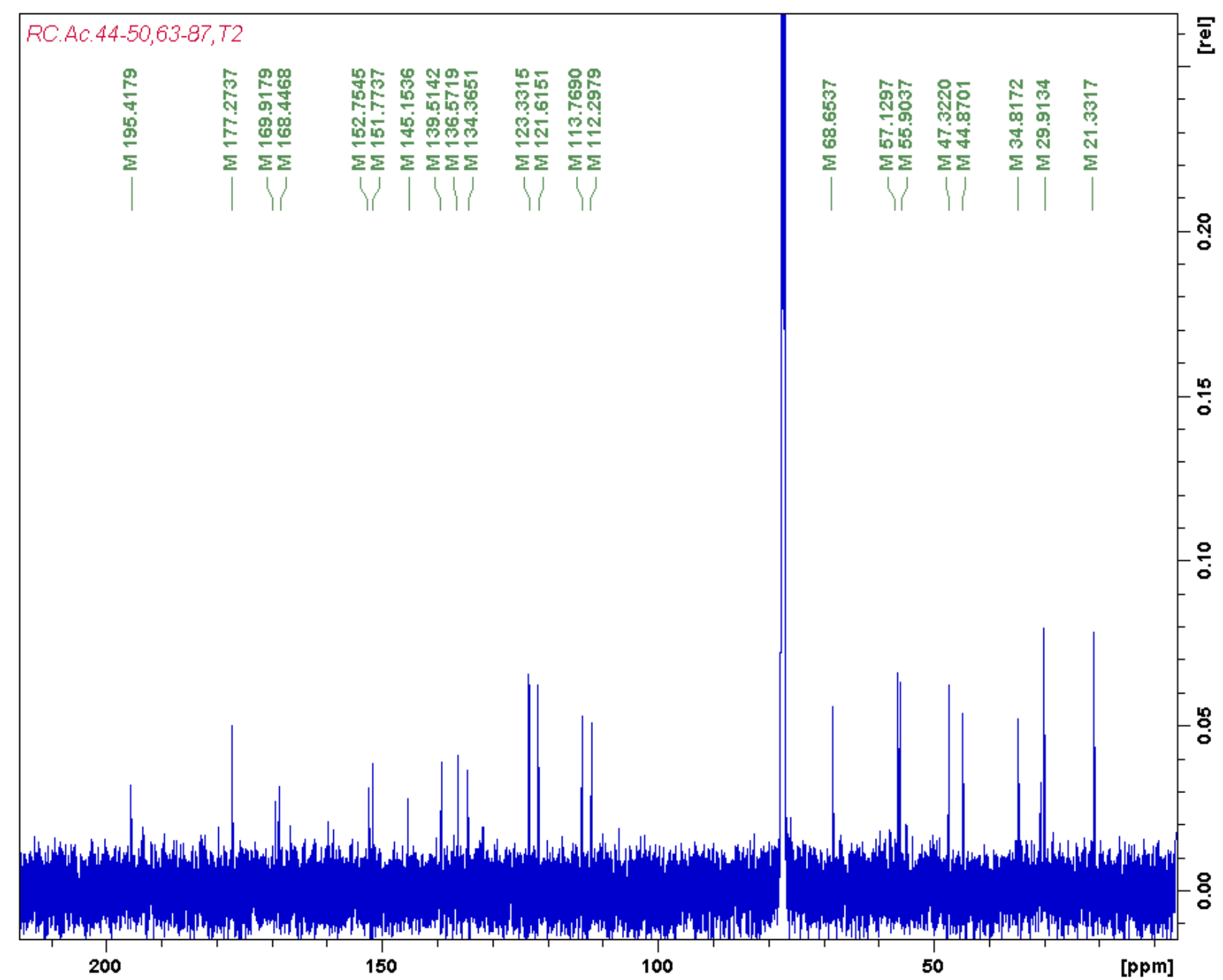


${ }^{1}$ H NMR spectrum for compound 3

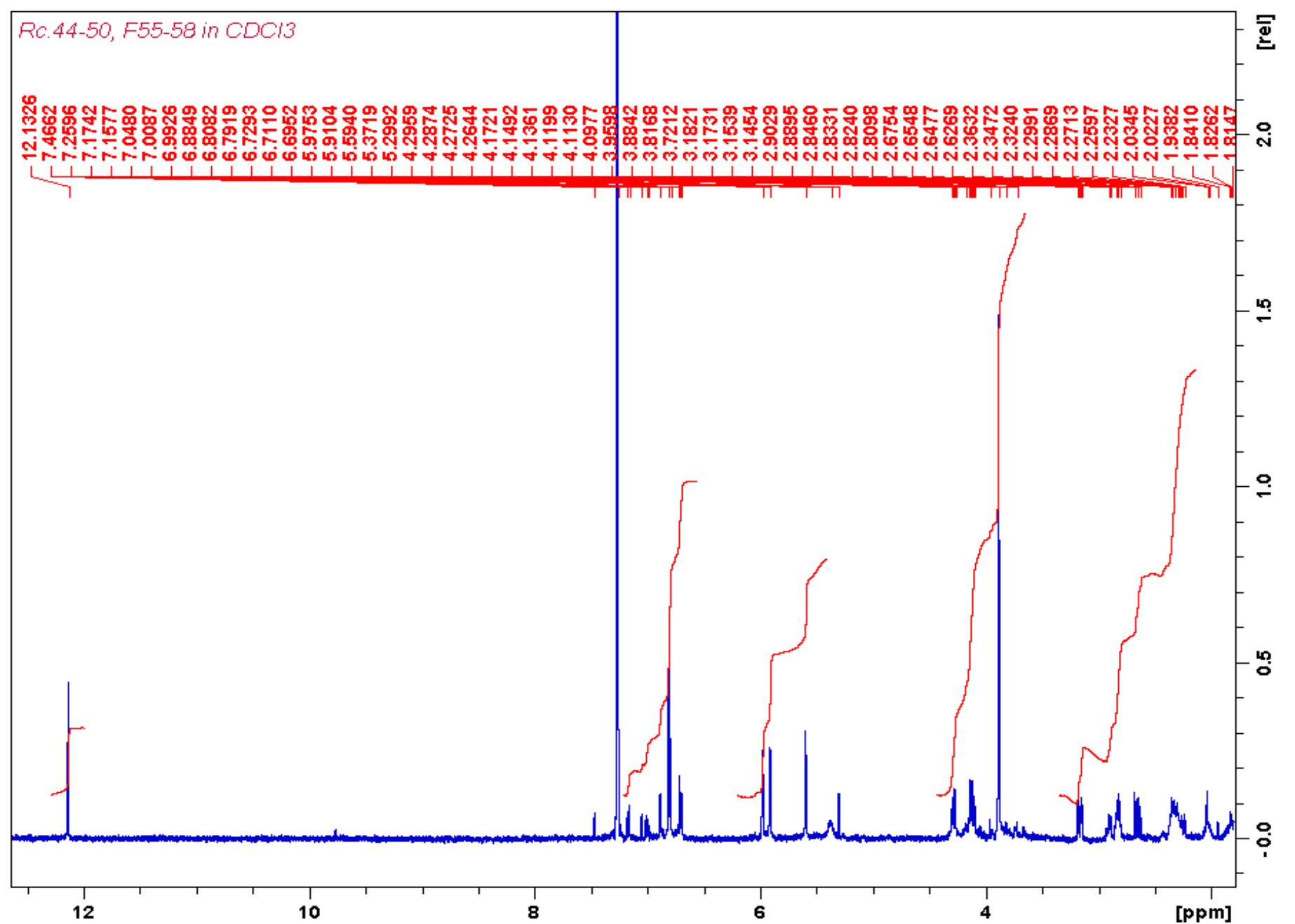


${ }^{13} \mathrm{C}$ NMR spectrum for compound 3

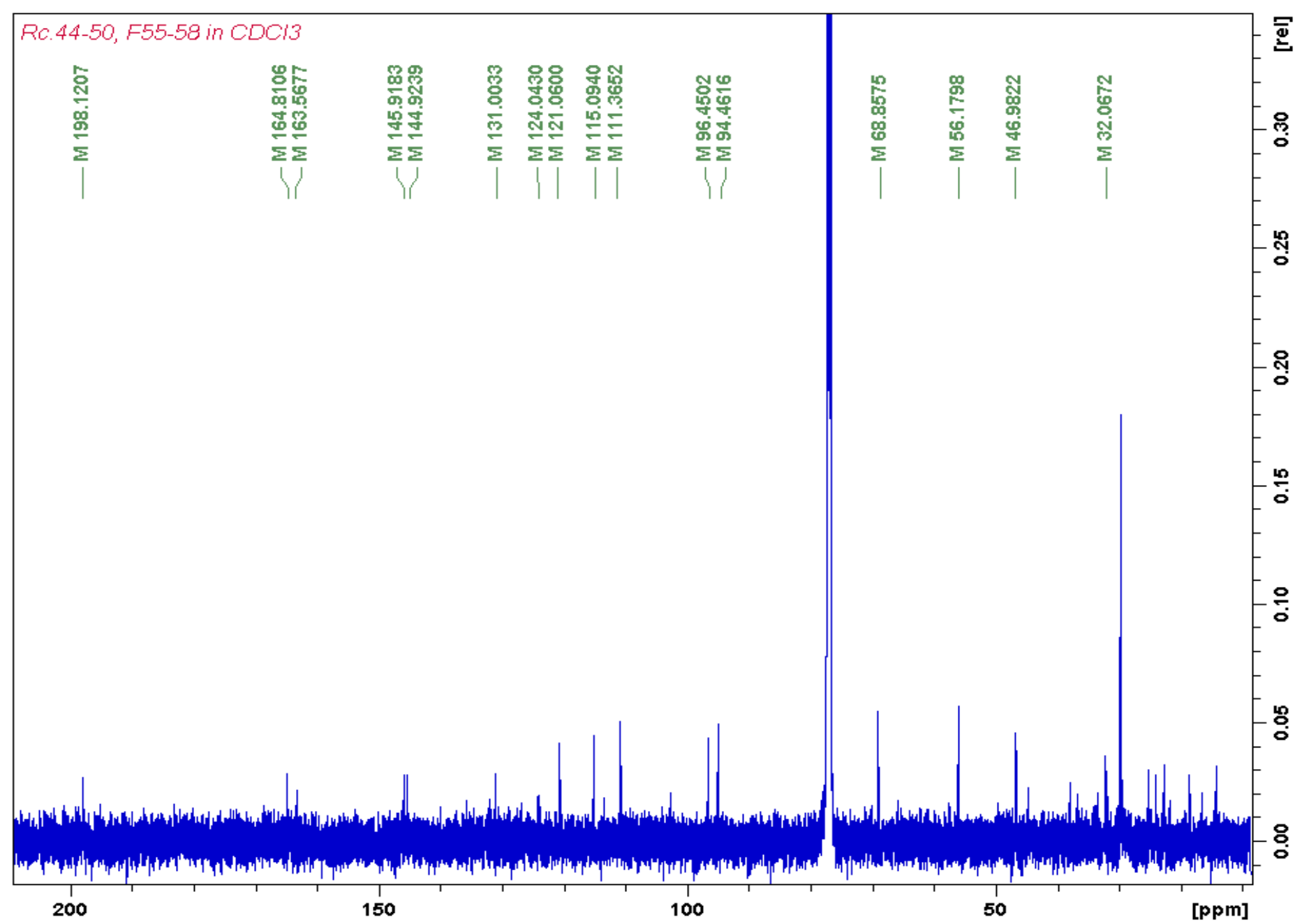


${ }^{1}$ H NMR spectrum for compound $3 A$

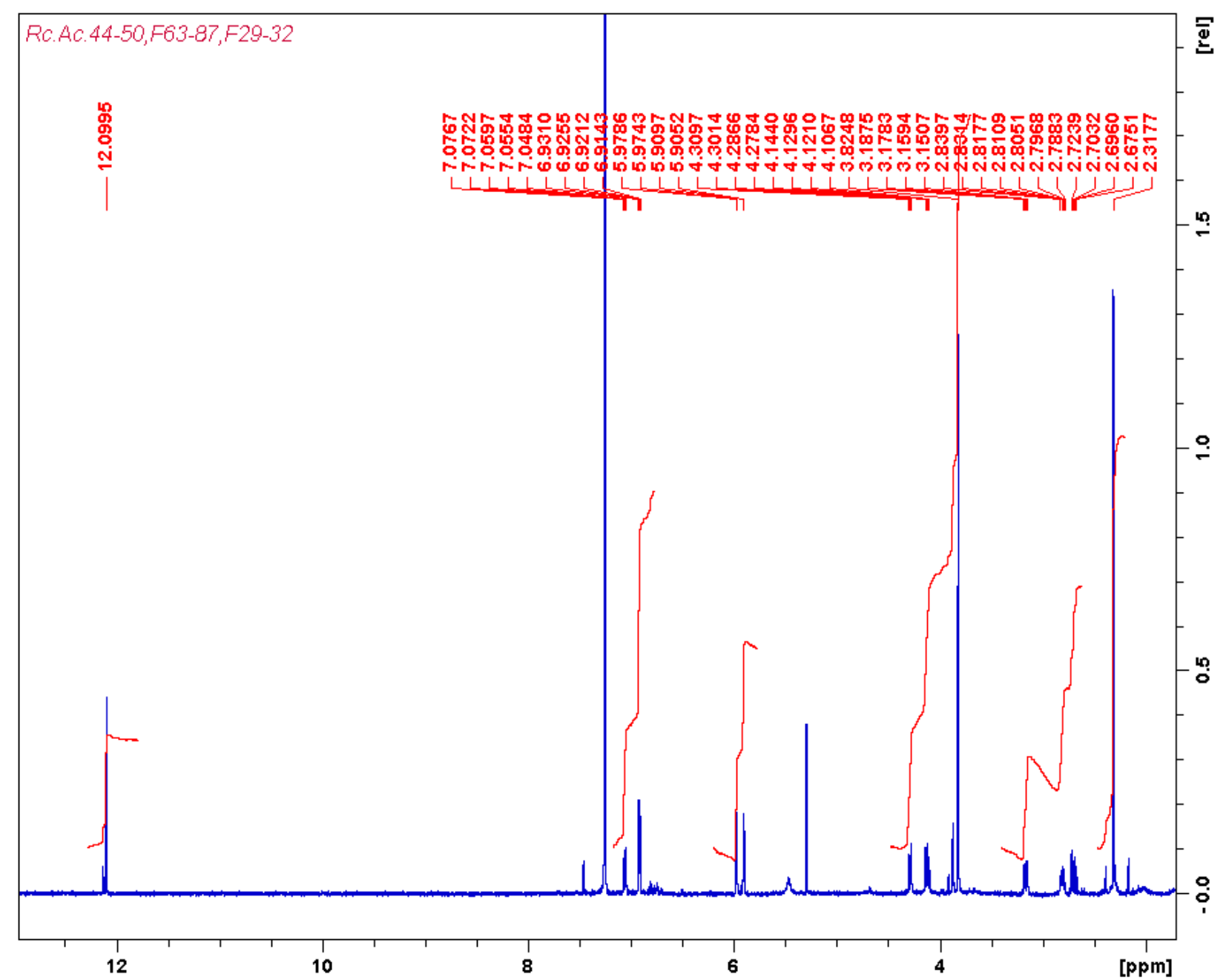


${ }^{13} \mathrm{C}$ NMR spectrum for compound $3 \mathrm{~A}$

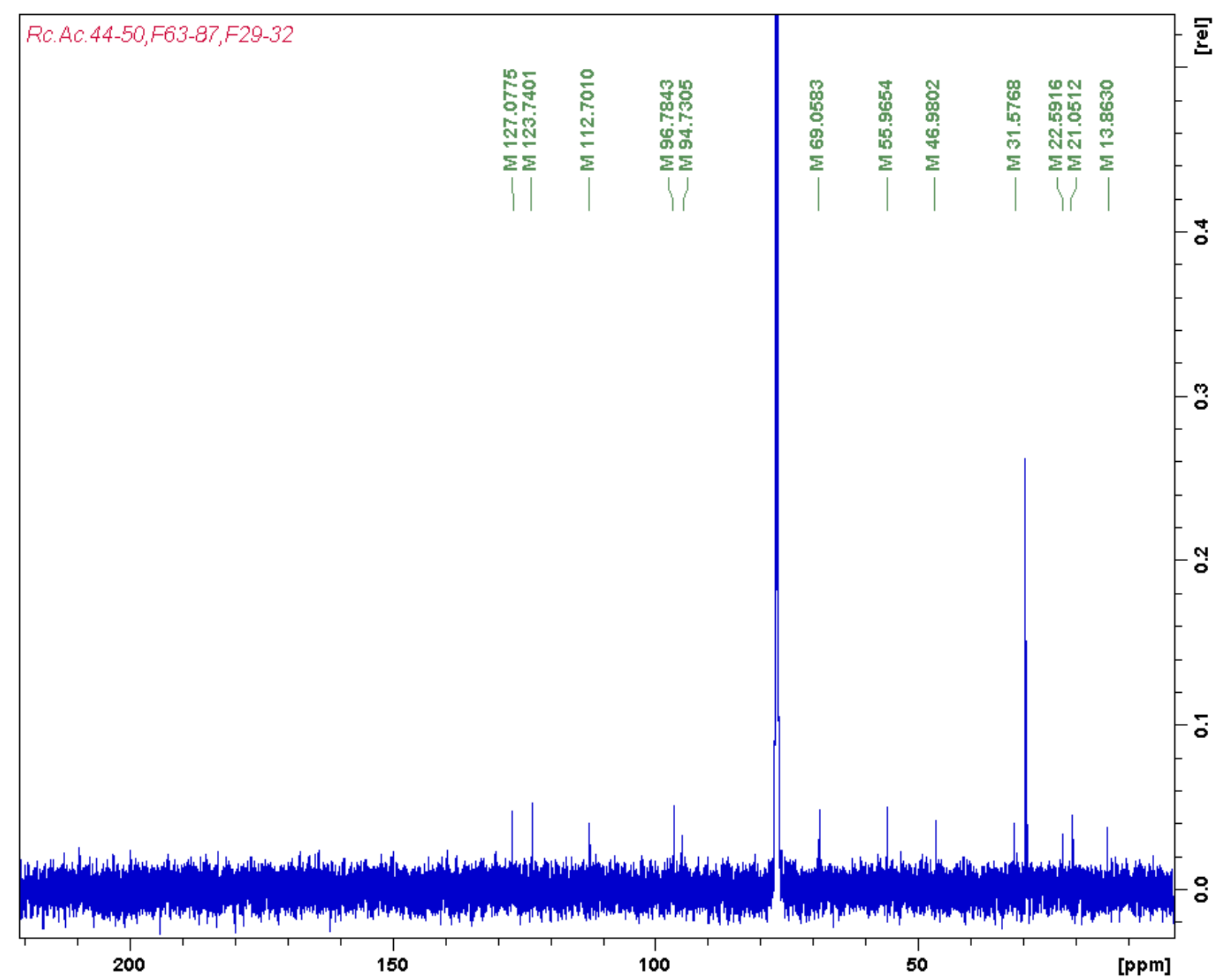


${ }^{1} \mathrm{H}$ NMR spectrum for $3 B$

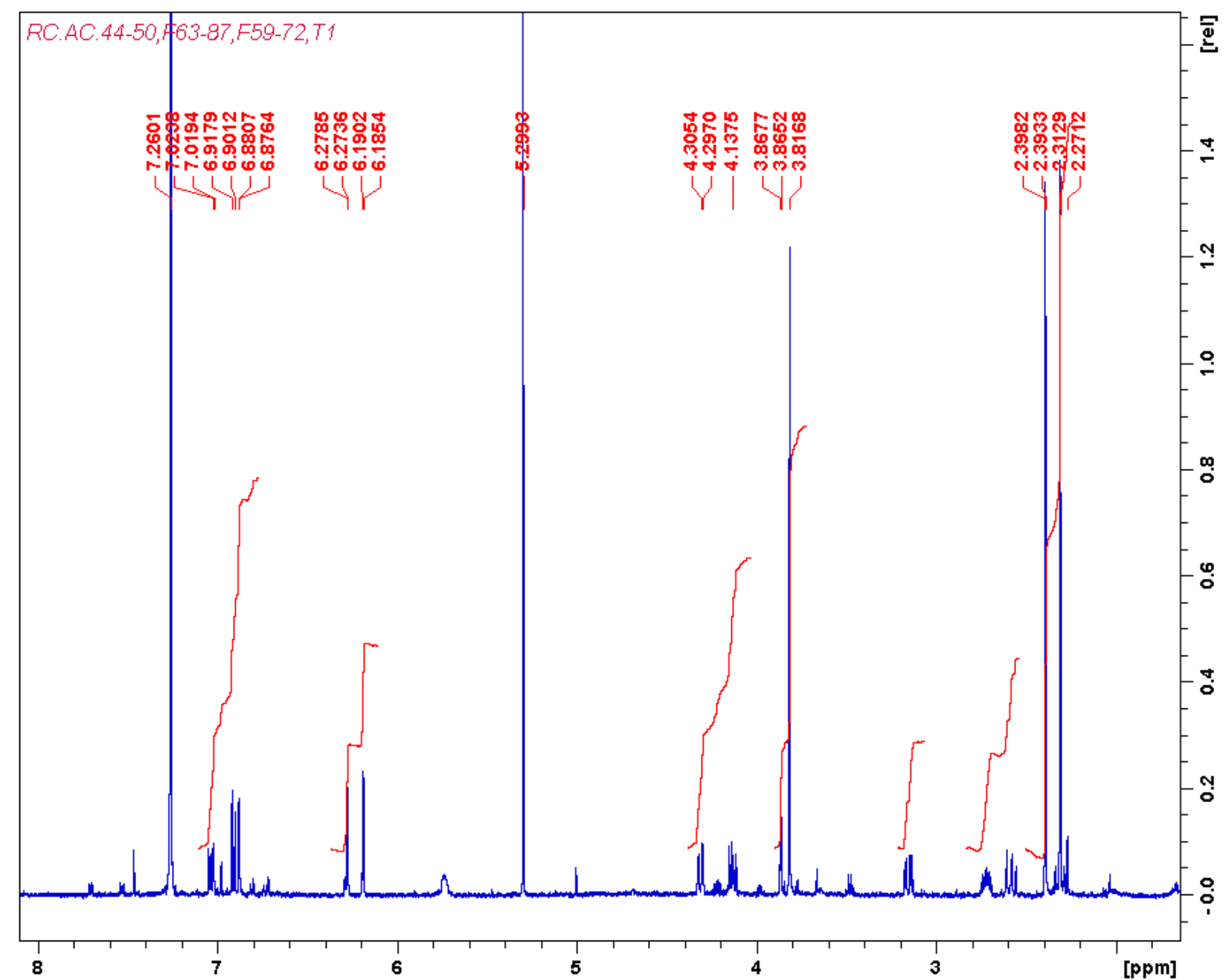


${ }^{13}$ C NMR spectrum for compound 3B

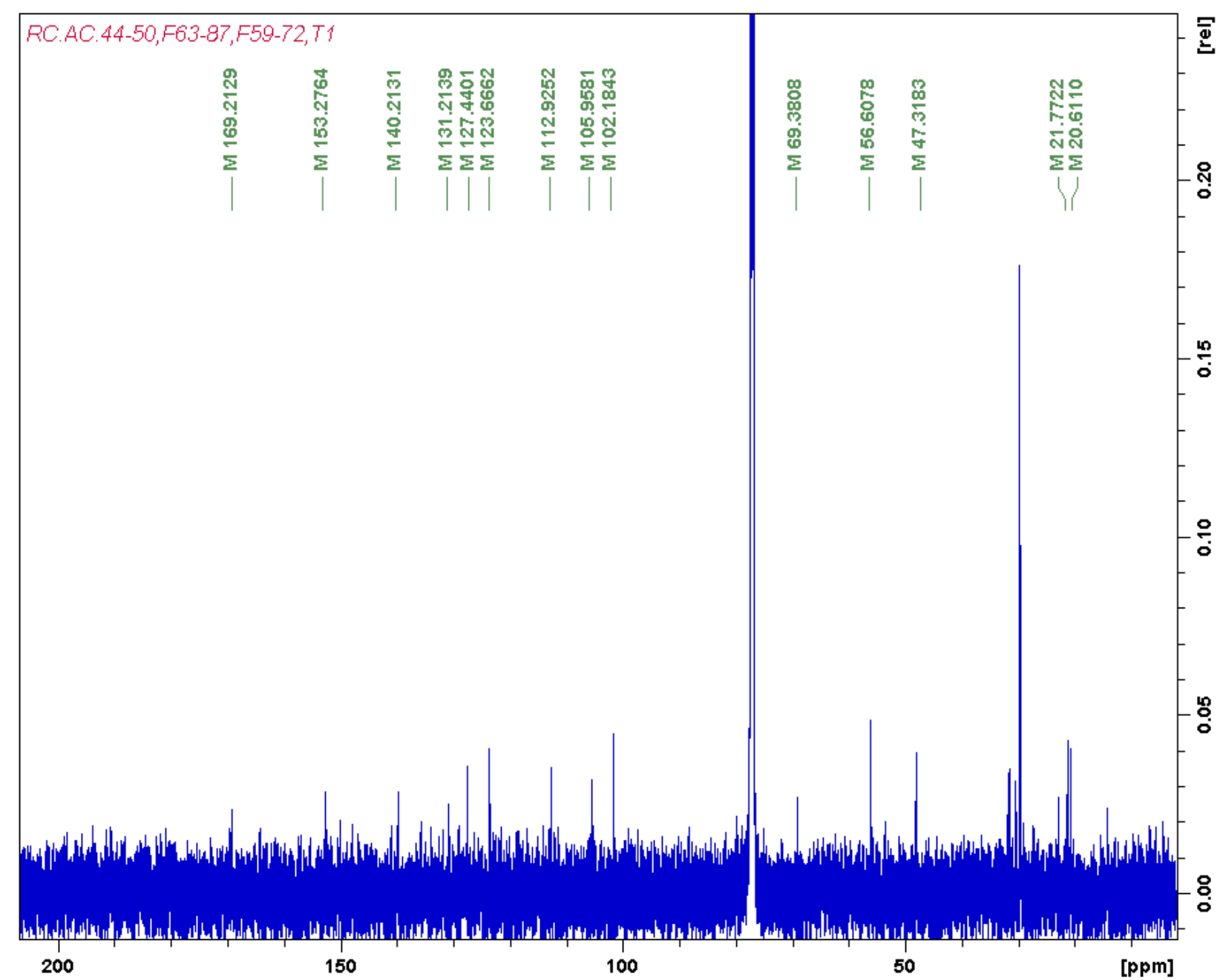


${ }^{1}$ H NMR compound for 6

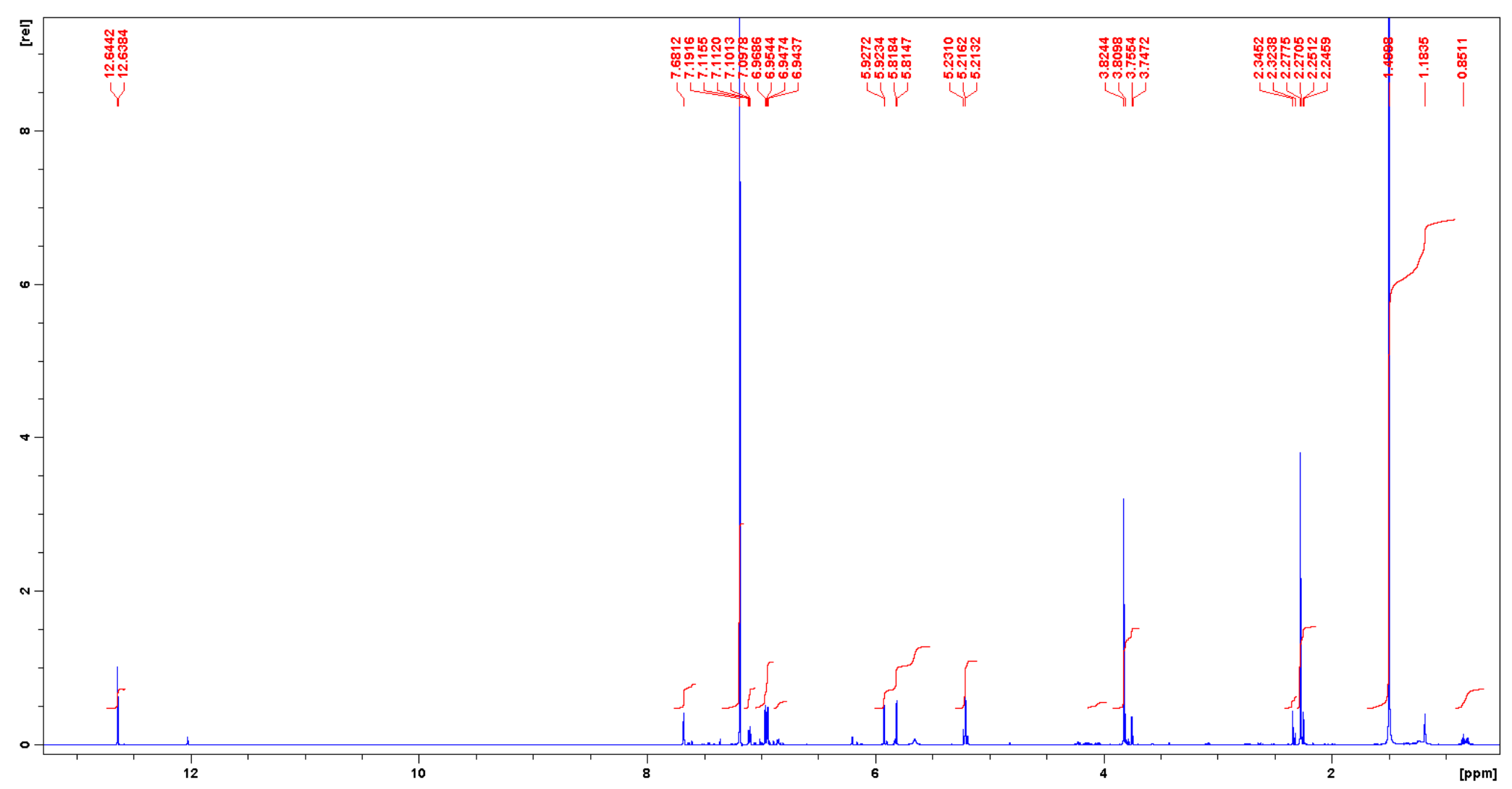


DEPT NMR spectrum for 6

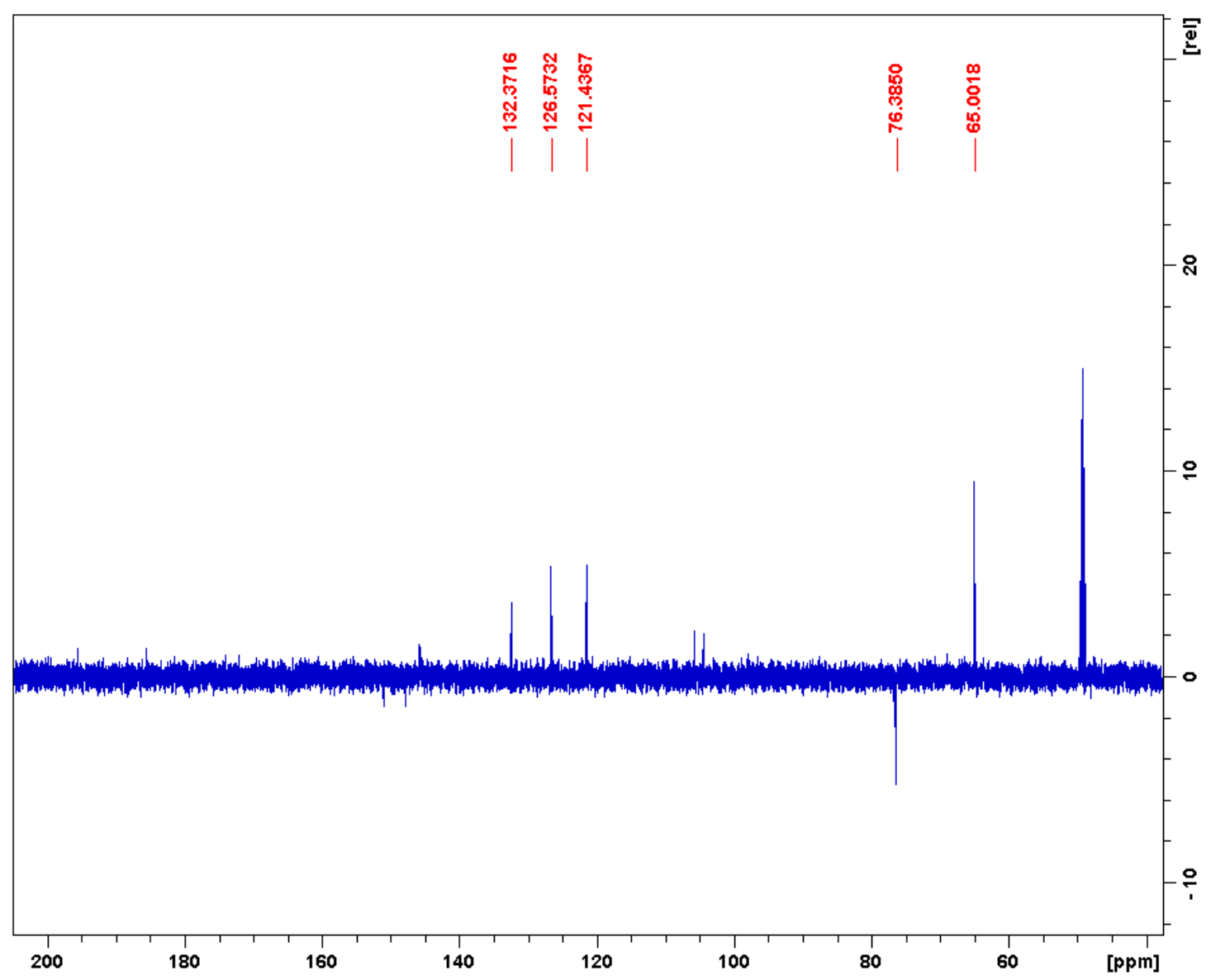


${ }^{1} \mathrm{H}$ NMR compound for $7 \mathrm{~A}$

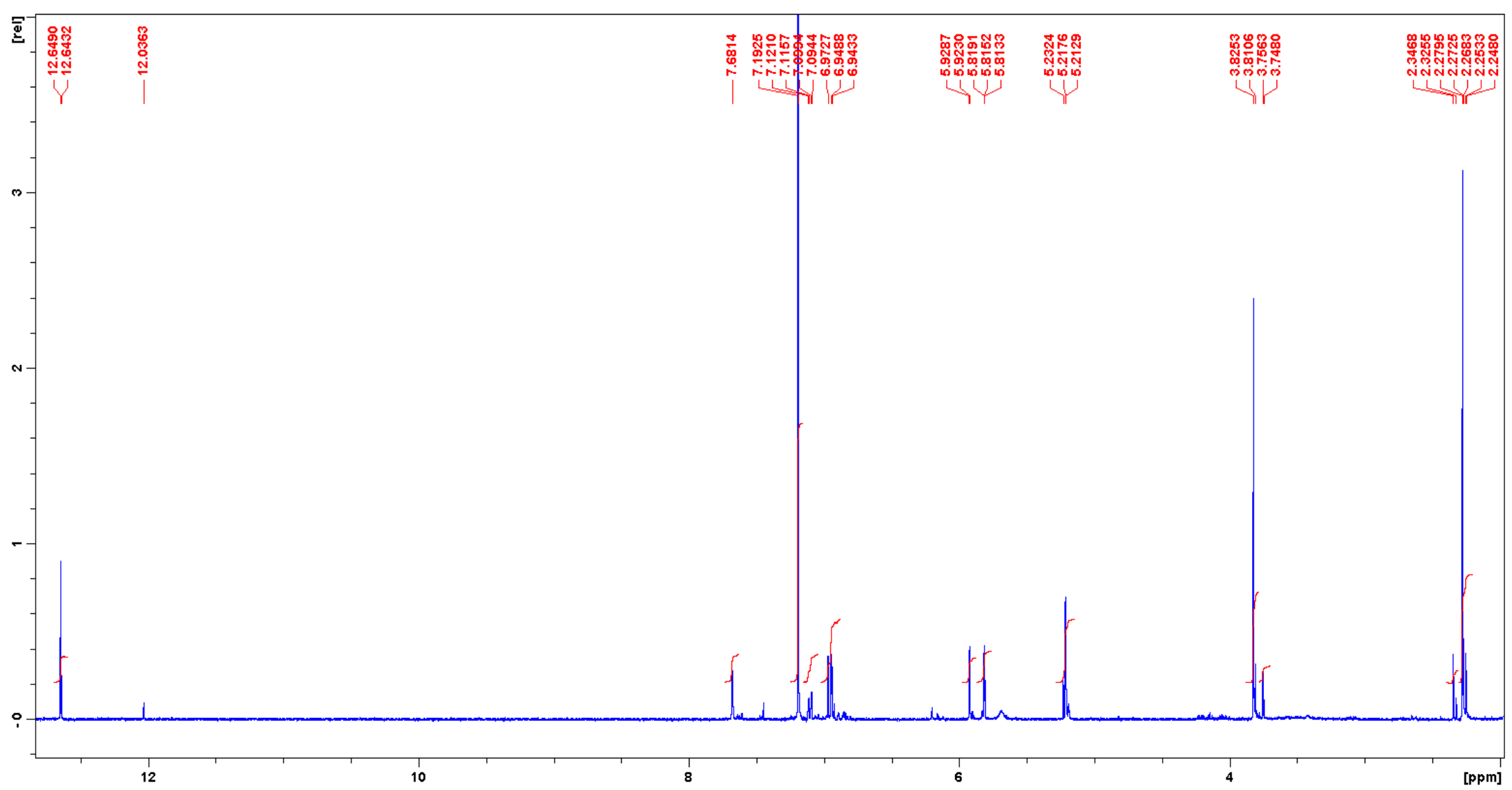


DEPT-Q NMR spectrum for 7A

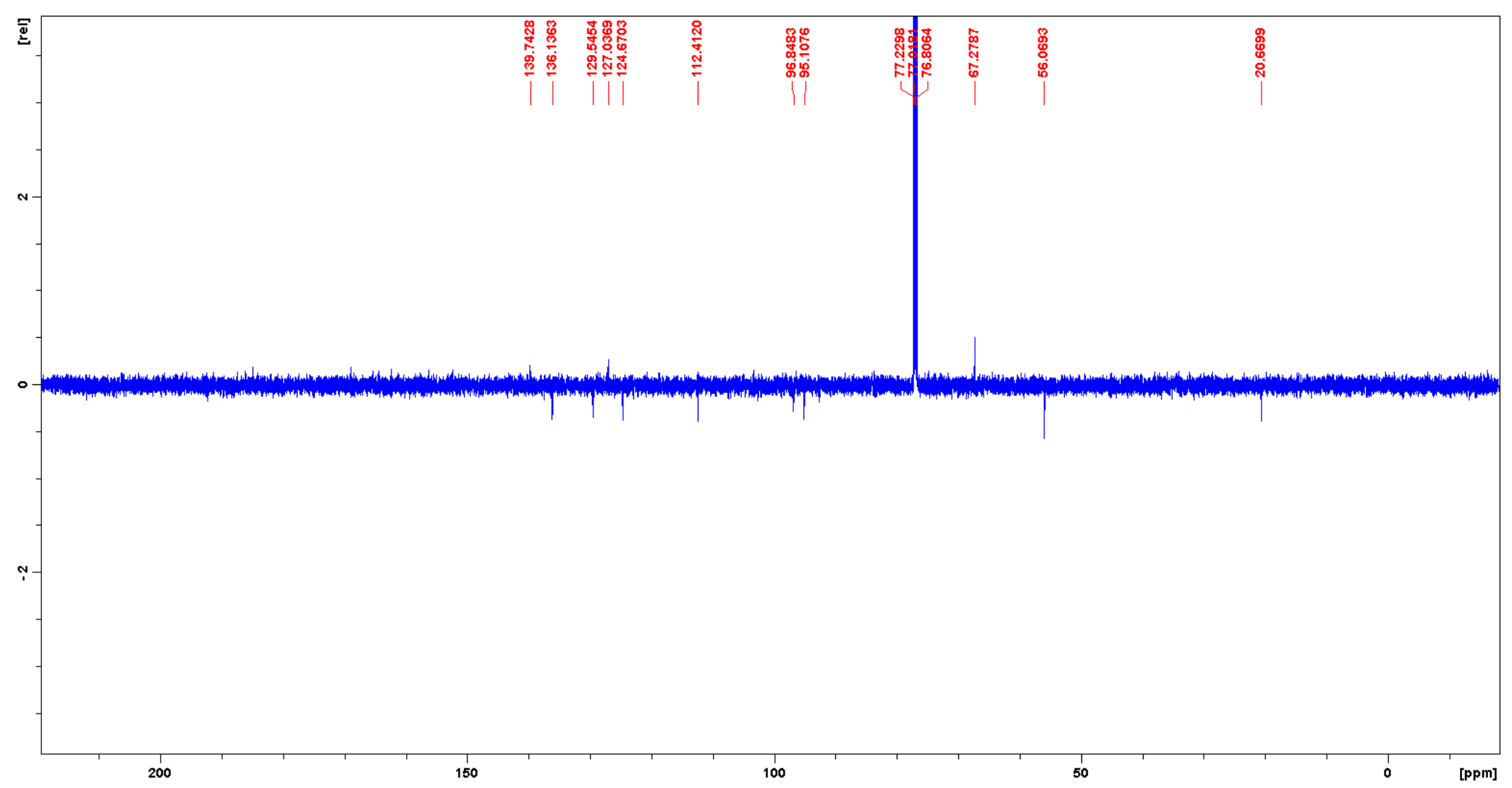


${ }^{1}$ H NMR compound for 8

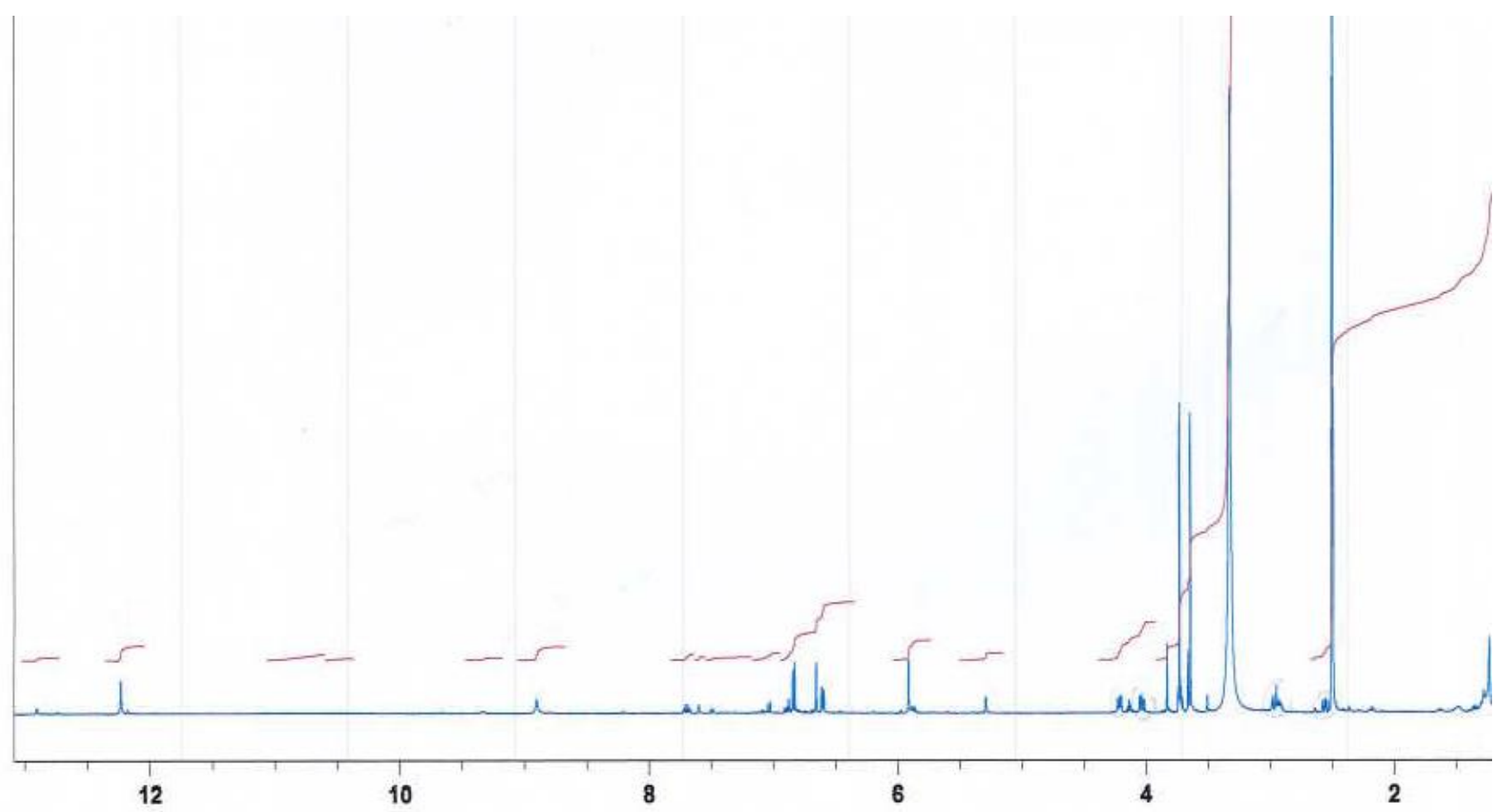


DEPT-Q NMR spectrum for 8

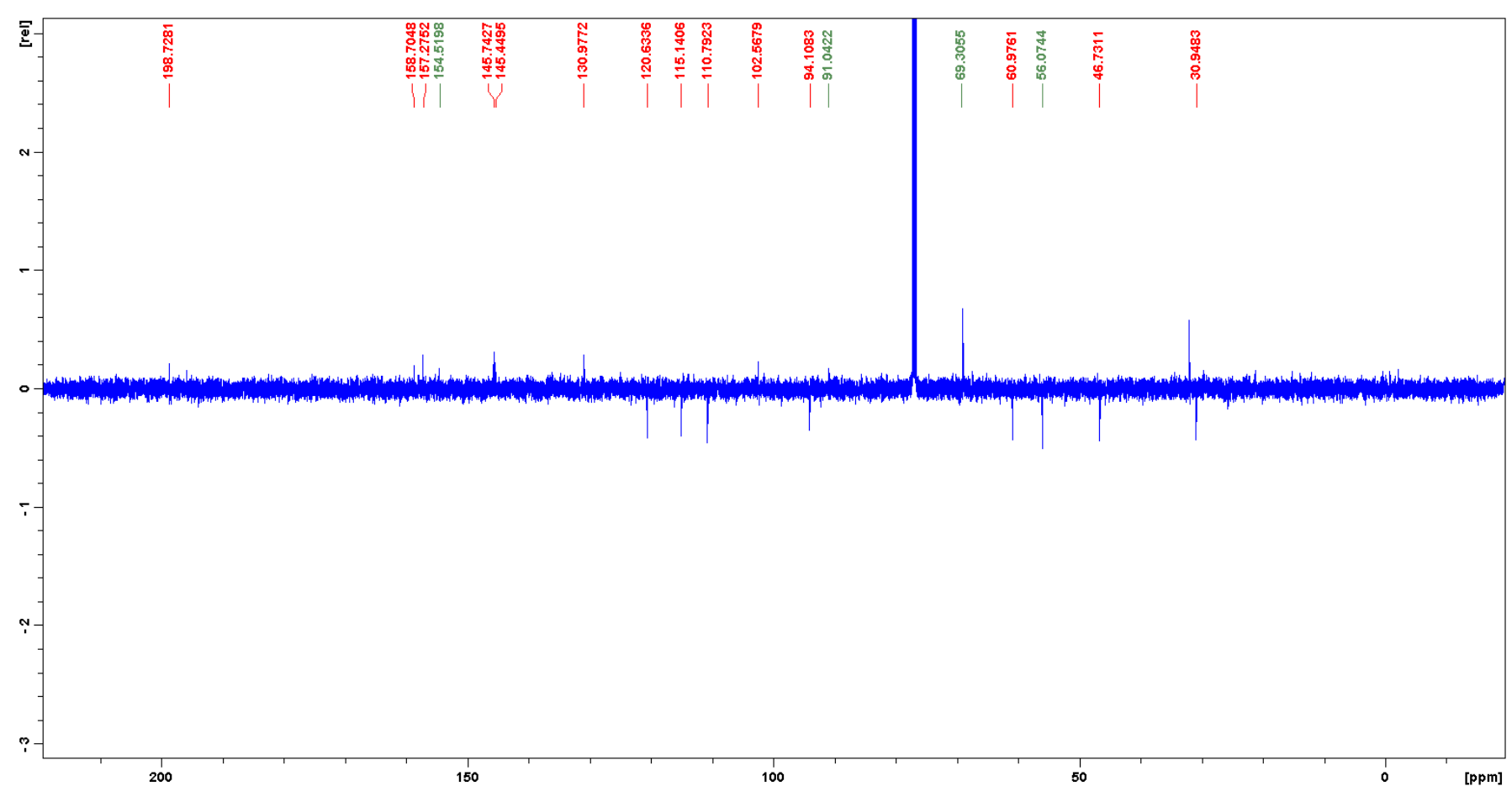


S3: Figures S1 - S3

\begin{tabular}{|c|c|}
\hline 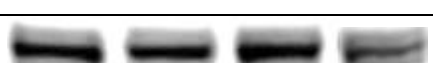 & COX-2 (72 kDa) \\
\hline 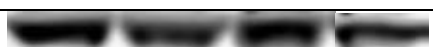 & $\beta$-Actin $(42 \mathrm{kDa})$ \\
\hline
\end{tabular}

\begin{tabular}{|c|c|c|c|}
\hline 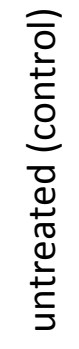 & 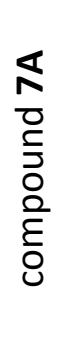 & 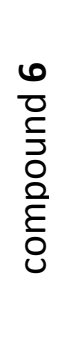 & 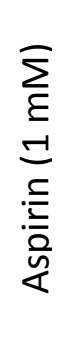 \\
\hline
\end{tabular}

Figure S1. Effect of compounds 6 and 7A on COX-2 expression in HCA-7 cells $n=$ at least three separate experiments. 


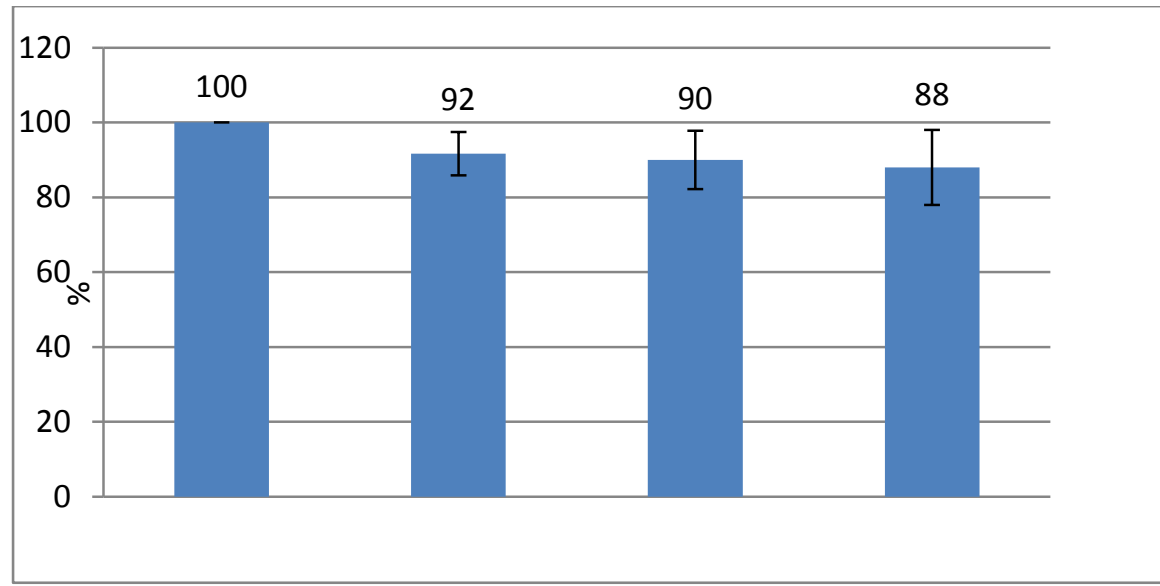

Untreated control

compound 7A

compound 6

Aspirin $1 \mathrm{mM}$

Figure S2. Quantitative analysis of western blots of the effect of compounds 6 and 7A and aspirin (1 mM) on COX-2 expression in HCA-7 cell Data were normalized against $\beta$-actin (the internal control) and expressed in comparison to the control (the untreated control) which is $100 \%$. $n=3$ 


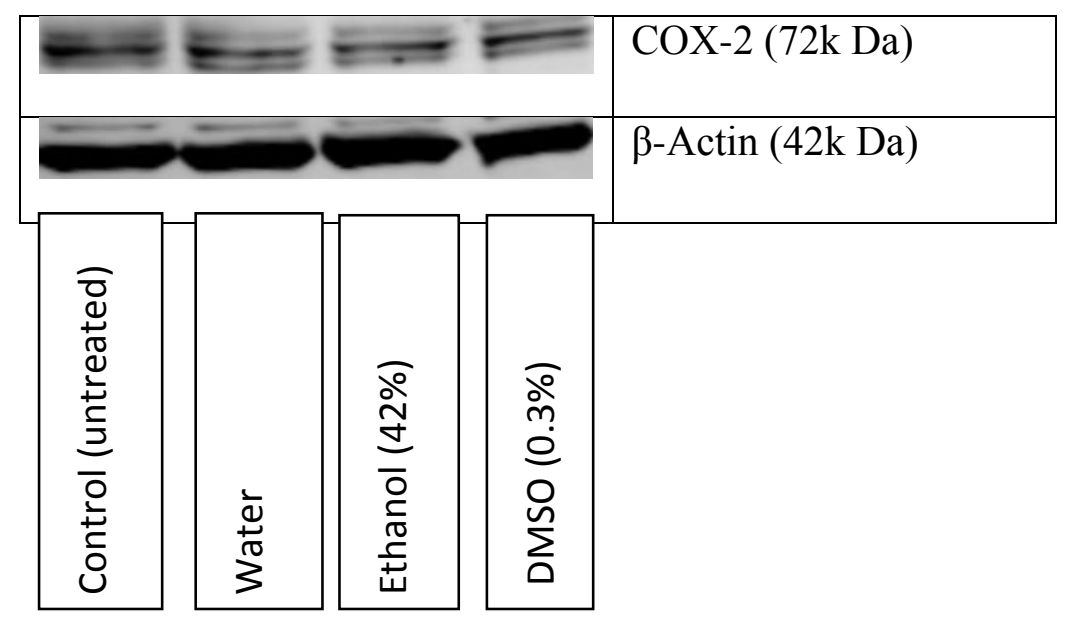

Figure S3. The effect of untreated control, 0.3\% DMSO and other vehicle controls on COX-2 expression in HCA-7 cells. 